\title{
حرية|الرأىوالتعبير فييئة|الإنترنت
}

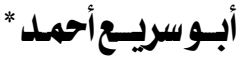

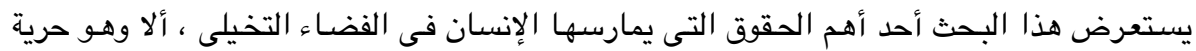

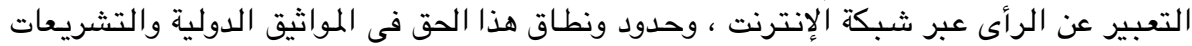

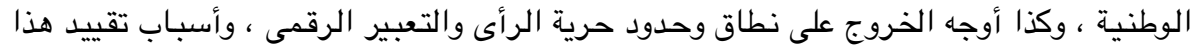

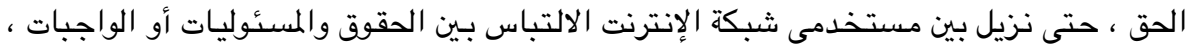

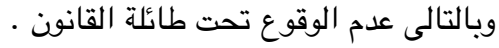

\section{مقدمــة}

تطورت أنواع وأشكال الحقوق التى يستطيع أن يمارسها الإنسان ويتمتع بها بدءاً من

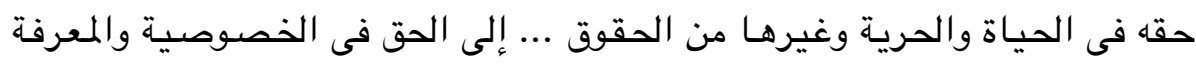

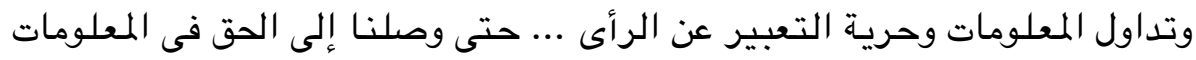
الرقمية وتداولها أو ما سمى بالحقوق الرقمية الناجمة عن التطور فى التكنولوهيا

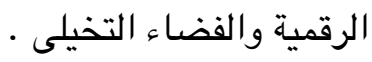

وقد جاء هذا التطور فى أنواع الحقوق التى يستطيع الإنسان أن يمارسها

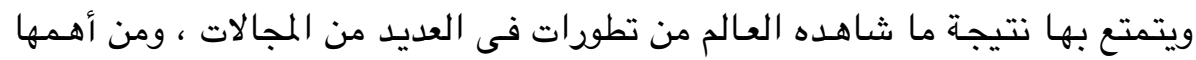
التطور فى جمع المعلومات وتخزينها وتداولها واستخدامها فى جميع مظاهر الحياة حتى أصبحت العمود الفقرى لتطود وتقدم الأمم فى ظل ثورة المعلومات أو انفجار

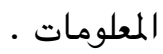
* مقدم دكتور ، الإدارة العامة للمعلومات ، وزارة الداخلية . 
ولم يقف الأمر عند هذا الحد ، بل إن التطور التكنولوجى المستمر والتطور فى مجالات تكنولوجيا المعلومات بجميع مفرداتها وتقدم نظم الحوسبة والتقنيات الرقمية وتزاوجها واندماجها مع ثورة تقنيات الاتصالات وشبكاتها ، أدى إلى التطور فى تداول المعلومات الرقمية وسهولتها وسرعتها دون التقيد بمكان أو زمان ؛ متخطية جميع العوائق والحواجز التى قد تضعها الدول أو الحكومات للسيطرة عليها ، وأضحى للإنسـان حقوق معلومـاتية وأخرى رقمية أفرزتها تلك التطورات فى مجال المعلومات والتقنيات الرقمية ، حقوق يسعى الإنسان للمناداة بها والمحافظة عليها ويحارب من

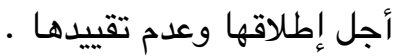
هـذا التطور فى حقوق الإنسـان دفع الأمم المتحدة ودول العالم إلى التكاتف لوضع مبادئ وضوابط لممارستها والمحافظة عليها ، وحث جميع الدول على المشاركة فى معطياتها وحريتها طبقاً لمبادئ ومقاصد الأمم المتحدة . والحقيقة التى لا مراء فيها أن حقوق الإنسان فى العصر الرقمى تمتـ جذورها منذ بداية تسعينيات القرن الماضى ، بيد أن الظهور الحقيقى والواضس لهذه الحقوق قد اقترن بالانتشـار السريع لشبكة الإنترنت مع بدايـة النصف الثانى لتسعينيات القرن الماضى وما تلاه(') ، حيث بدأت الحقوق الرقمية للإنسان فى التوهج وكسب مزيداً من النضج والوضوح والتعدد مع الانتشار المتتامى لشبكة الإنترنت واستخدامها فى جميع مناحى الحياة ومجالاتها وبخاصـة كأداة للتعبير عن الرأى والمشـاركة المجتمعية وممارسة الديمقراطية الرقمية وجميع أشكال المعارضة ومراقبة الحكومات ، مما جعل من هذه الثبكة وما يتداول وييث على صفحـاتها مثاراً وجدالاً بـين أطراف إنسـانية متعددة كل منها يبحث عن حقوقه ومصالحه فيها . هـذه الثورة الرقمية المتفجرة والاستخدام المتنامى لشبكة المعلومـات الدولية (الإنترنت) وما أرسته من وسائل ونظم للمعرفة وتداول المعلومات وتحقيق مفهوم حرية 
المعلومات ، وكذا ما منحته للبشرية من خصائص وميزات ، جعلت البعض يصنفها كأحد أعظم اختراعات البشريـة ، ويـات على الدول أن توفر البيئة التمكينية الملائمة لممارسة الإنسان لحقوقه الرقمية الناجمة من تعامله مع شبكة الإنترنت .

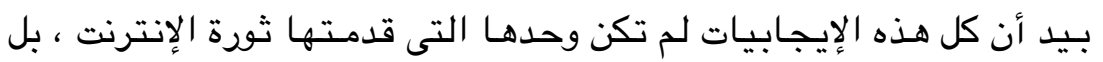
رافقتها ظواهر سلبية متعددة أدت إلى الاعتداء على حريات الآخرين وحقوقهم كالحق فى الخصوصية والملكية الفكرية وغيرها من الحقوق ، كما تمثلت هذه الظواهر السلبية فى بث مواد تـهدد أمن الدول أو سلامتها أو مستخدمى شبكة الإنترنت أو تخالف

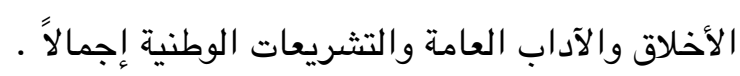
ولم تستثن الشبكة العالمية للمعلومات من الصـراع الدائر بين الحكومات والشعوب حول حرية التعبير وإبداء الرأى والحق فى التجمعات فى الفضاء التخيلى ، ودافع كل من الفريقين (الحكومات مـن جانب ، ومستخدمسى شبكة الإنترنت من جانب آخر) عن وجهة نظره وحقوقه فى تقييد وتقليص حقوق الجانب الآخر . ونظراً لما لمسناه من خلط حول مفهوم الحرية فى ممارسة الحقوق المتنوعة على ولى ولى شبكة الإنترنت ، وعلم الإلمام بالمواثيق الدولية والتشـيعات الوطنية لدى الكثير من مستخدمى شبكة الإنترنت ، وهـو الأمر الذى يؤدى إلى الوقوع تحت طائلة القانون فى

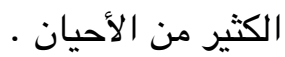
فسنعرض فى هذا البحث أحد أهم الحقوق التى يمارسـها الإنسـان فى الفضاء التخيلى ، ويتمثل فى حرية التعبير عن الرأى عبر شبكة الإنترنت ، وحدود ونطاق هذا الحق والمواثيق الدولية والتشريعات الوطنية التى تثبت للإنسان الحق فى ممـارسته ، وتلقى على عاتق الدول مسئولية تمكين مواطنيهـا من ممارسـة هـذا الحق فى بيئة الإنتـرنت ، وكذا أوجه الخروج على نطـاق وحدود حريـة الرأى والتعبير الرقمى ،

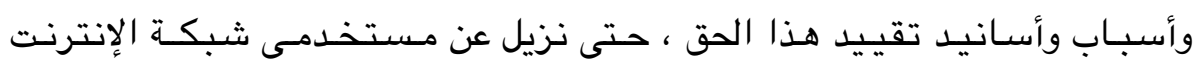
الالتباس بـين الحقوق والمسئوليات أو الواجبات ، وبـالتالى عدم الوقوع تحت طائلة 


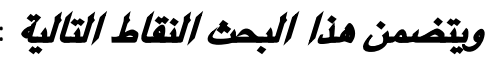

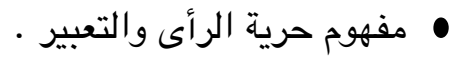

$$
\begin{aligned}
& \text { • التطور التاريخى لحرية الرأى والتعبير • } \\
& \text { القيود الدولية على حرية الرأى والتعبير . } \\
& \text { • حدود ونطاق حرية الرأى والتعبير فى التشريعات الوطنية . } \\
& \text { • حرية الرأى والتعبير فى بيئة الإنترنت . } \\
& \text { مأدوات ممارسة حرية الرأى والتعبير فى بيئة الإنترنت . }
\end{aligned}
$$

\section{أولا : مفهومحرية|أرأىوالتعبير}

الحرية لغة هى حالة الكائن الحى الذى لا يخضع لقهر أو غلبة أى يتصرف طبقاً

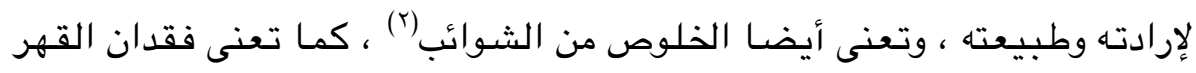
والإرغام والقدرة على الاختيار والتفضيل .

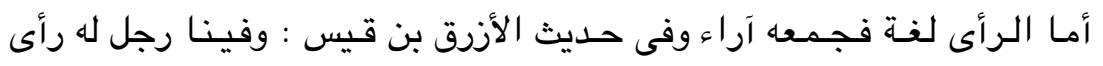

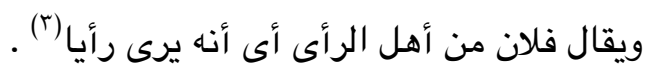

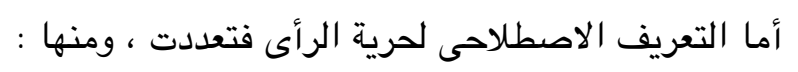

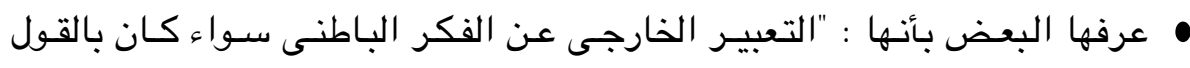

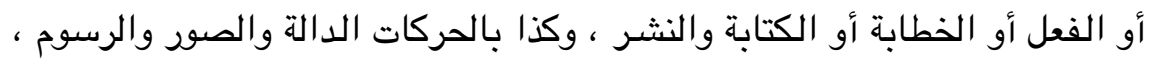

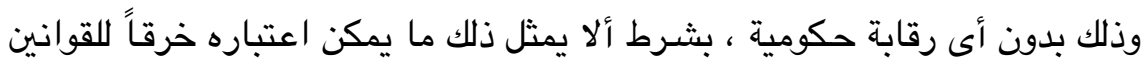

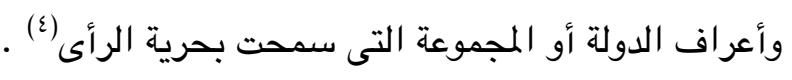

وذهب آخرون إلى تعريف حرية الرأى بأنها : "قدرة الإنسان فى تكوين رأيه بناء على تفكيره الشخصى ، دون تبعية أو تقليد لأحد ، أو خوف من أحد ، وأن يكون له

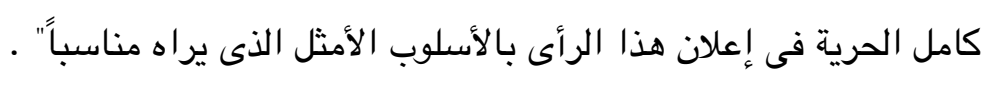


• ويرى آخر أن حرية الرأى هى الأم لكل الحريات الذهنية ، لأن الحريات الذهنية ما هى إلا مظهر من مظاهر حرية الرأى(0) . • كما يرى آخر أن حرية الرأى هى : "روح الفكر الديمقراطى لأنها تحوى ما يجول

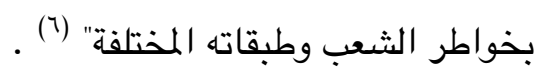
• كما عرف البعض حرية التعبير على أنها : "الحرية فى التعبير عن الأفكار والآراء عن طريق الكلام أو الكتابة أو الأعمال الفنية بدون رقابة أو قيود حكومية بشرط أن لا يمثل طريقة عرض الأفكار والآراء أو مضمونها ما يمكن اعتباره خرقا أو مخالفة لقوانين وأعراف الدولة أو المجموعة التى سمحت بحرية التعبير ، ويصاحب حرية الرأى والتعبير على الأغلب بعض أنواع الحقوق والحدود مثل حق حرية العبادة وحرية الصحافة وحرية التظاهرات السلمية"(() .

\section{ثانياً : التطور التّاريخى لحرية/الرأىوالتقبير}

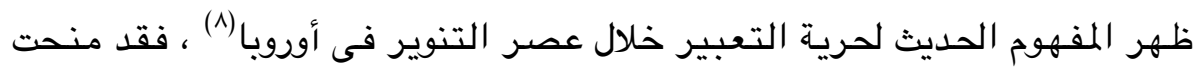

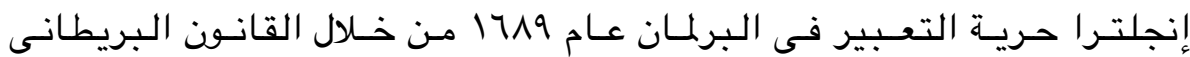
(شرعية الحقوق) الذى يعد أحد الصكوك الأساسية للقانون الدستوى الإنجليزى ، لإسل وكذا إعلان حقوق الإنسان والمواطن بفرنسا الذى اعتمد خلال الثورة الفرنسية VA99 الذى يعد واحداً من المبادئ الأساسية للحريات والثورة الفرنسية وبمثابة ديباجة لدستور IV9I والذى أورد المبدأ الأساسى فيه على أنه : "يولد جميع الناس أحراراً ومتساوين فى الحقوق" ، وأضاف فى المادة الحادية عشرة النص على : "حرية التعبير

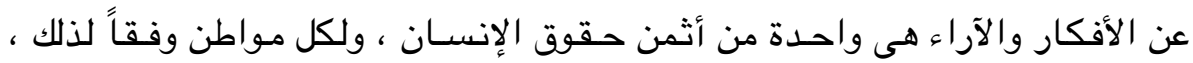
التحدث والكتابـة والطباعة بحرية ، لكن يجب أن تكون مسئوليته عن مثل هذه الانتهاكات لهذه الحرية وفقاً لما يحدده القانون" . 
وفى العصر الحديث نادت الدول بإطلاق الحق فى حرية الرأى والتعبير ، وأن القيود التى يجب أن ترد على هذا الحق يجب أن تكون مـددة ، ولأجل ذللك عقدت الاتفاقيات والمعاهـات الدولية لتكريس حقوق الإنسان الأساسية والحق فى حرية إبداء الرأى والتعبير ، ومن أهمها :

أولاً : الإعلان العالمى لحقوق الإنسان 19 19 ، المادة 19 التى تنص على أنه : "لكل شخص الحق فى حرية الرأى والتعبير ، ويشمل هذا الحق حرية اعتناق الآراء دون أى تدخل ، واستقاء الأنباء والأفكار وتلقيها وإذاعتها بأية وسيلة كانت دون تقيد

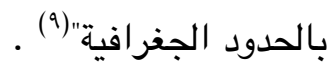

ثانياً : الاتفاقية الأوروبية لحقوق الإنسان •190|(·) ، حيث ورد فى المادة

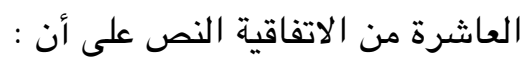

1- لكل إنسان الحق فى حرية التعبير ، هذا الحق يشمل حرية اعتناق الآراء وتلقى وتقديم المعلومات والأفكار دون تدخل من السلطة العامة ، وبصرف النظر عن الحدود الدولية ، وذلك دون إخلال بحق الدولة فى طلب الترخيص بنثاط مؤسسات

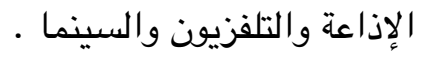

ץ- هذه الحريات تتضمن واجبات ومسئوليات ، لذا يجـوز إخضـاعها لشكليـات إجرائية ، وشروط ، وقيود ، وعقوبات محددة فى القانون حسبما تقتضيه الضرورة

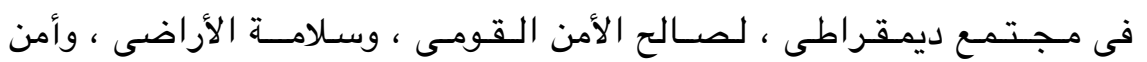
الجماهير وحفظ النظام ومنـع الجريمـة ، وحمايـة الصحـة والآداب ، واحترام

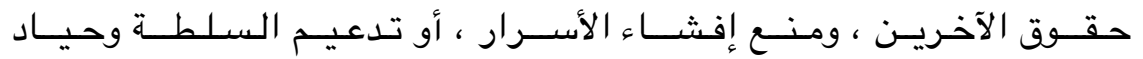

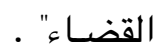




$$
\begin{aligned}
& \text { ثالثا" : الاتفاقية الدولية للحقوق المدنية والسياسية 1977(") ، حيث ورد النص } \\
& \text { في المادة 19 - منها على أنه : } \\
& 1 \text { - لكل إنسان الحق فى اعتناق الآراء دون مضايقة . } \\
& \text { r - لكل إنسـان الحق فى حرية التعبير ، ويشمل هذا الحق حريته فى التمـاس مختلف } \\
& \text { ضروب المعلومات والأفكار وتلقيها ونقلها إلى آخرين دونما اعتبار للحدود ، سواء } \\
& \text { على شكل مكتوب أو مطبوع أو فى قالب فنى أو بأية وسيلة أخرى يختارها . } \\
& \text { r - تستتبع ممـارسـة الحقوق المنصوص عليها فى الفقرة r من هذه المادة واجبات } \\
& \text { ومسئوليات خاصـة ، وعلى ذلك يجوز إخضـاعها لبعض القيود ولكن شريطة أن } \\
& \text { تكون محددة بنص القانون وأن تكون ضرورية : } \\
& \text { أ - لاحترام حقوق الآخرين أو سمعتهم . } \\
& \text { ب - لحماية الأمن القومى أو النظام العام أو الصحة العامة أو الآداب العامة . } \\
& \text { لربعاً : الاتفاقيـة الأمريكيـة لحقوق الإنسـان 1979/(Ir) ، حيـث ورد فـى المـادة } \\
& \text { : با منها أنه } \\
& 1 \text { - لكل فرد الحق فى حريـة الفكر والتعبير ، ويشمل هـذا الحق حريته فى التماس } \\
& \text { وتلقى ونقل المعلومات والأفكار من جميع الأنواع ، دونما اعتبار للحدود ، سواء } \\
& \text { بالقـول أو الكتابة أو الطباعة أو الفن أو من خلال أى وسيلة أخرى من اختياره . } \\
& \text { Y - ولا تخضع ممارسة الحق المنصوص عليه فى الفقرة السابقة لرقابة مسبقة ولكنها } \\
& \text { تخضع لفرض المسئولية اللاحقة ، والتى تنشـأ صراحة بموجب القانون بالقدر }
\end{aligned}
$$

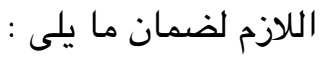

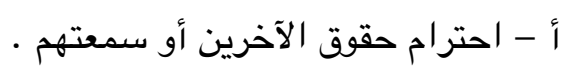


r تم لا يجوز تقييد الحق فى التعبير بأساليب أو وسائل غير مباشرة مثل تعاطى

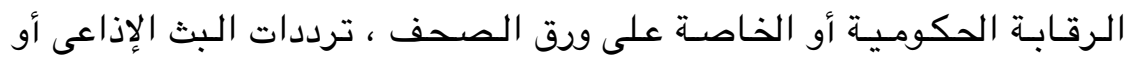

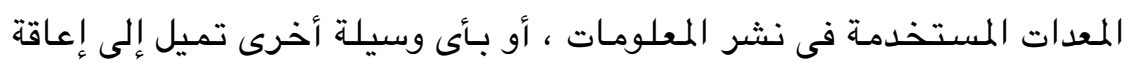

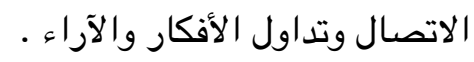

ع - وعلى الرغم من أحكام الفقرة Y أعلاه ، يمكن إخضاع وسائل التسلية العامة بحكم القانون للرقابة المسبقة لغرض وحيد هو تنظيم الوصول إليها من أجل

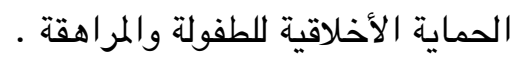

○ - أى دعاية للحرب وأية دعوة إلى الكراهية القومية أو العنصرية أو الدينية التى

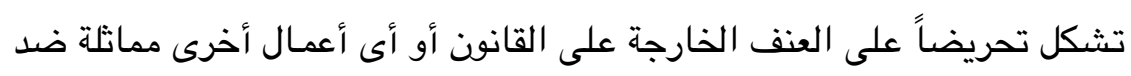

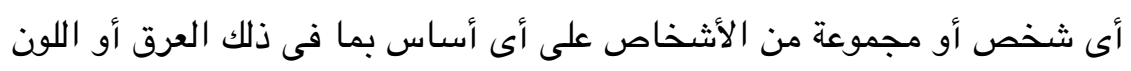
أو الدين أو اللغة أو وطنية تعتبر جرائم يعاقب عليها القانون . خامساً : إعلان اليونسكو حول دور الإعلام فى تعزيز السلام 19V^ حيث ينص

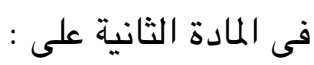
1 - ممارسة حرية الرأى والتعبير والمعلومات ، المعترف بها كجزء لا يتجزأ من حقوق

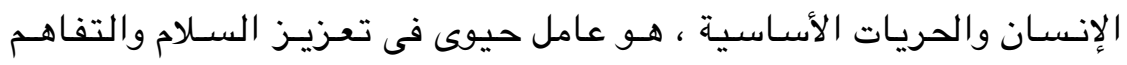

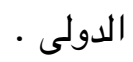
سادساً : الميثاق الإفريقى لحقق الإنسان 1911 ، حيث ورد فى المادة التاسعة

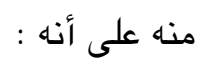
1 - من حق كل فرد أن يحصل على المعلومات . r - يحق لكل إنسان أن يعبر عن أفكاره وينشرها فى إطار القوانين واللوائح . 


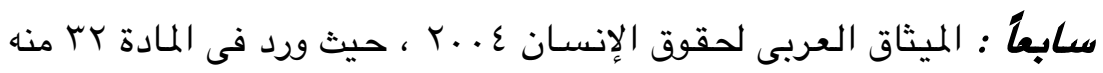

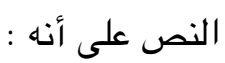

1 - يضمن هذا الميثاق الحق فى الإعلام وحرية الرأى والتعبير وكذلك الحق فى استقاء الأنباء والأفكار وتلقيها ونقلها إلى الآخرين بأى وسيلة ودونما اعتبار للحدود

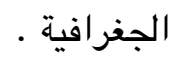

r - تمارس هذه الحقوق والحريات في إطار المقومات الأساسية للمجتمع ولا تخضع إلا للقيود التى يفرضهها احترام حقوق الآخرين أو سمعتهم أو حماية الأمن

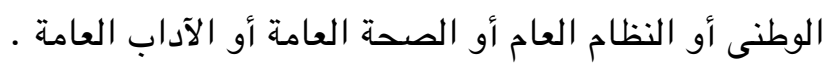

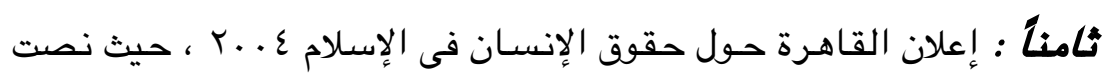

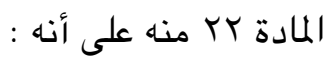
1 - لكل إنسان الحق فى التعبير بحريـة عن رأيه بشـكل لا يتعارض مـع المبادئ

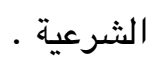

r - لكل إنسان الحق فى الدعوة إلى الخير والأمر بالمعروف والنهى عن المنكر وفقاً

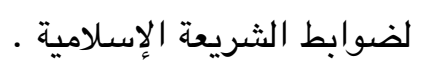

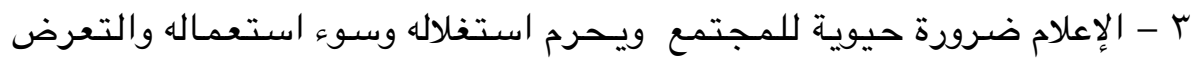
للمقدسـات وكرامة الأنبيـاء فيه ، وممارسـة كـل مـا من شـأنه الإخلال بالقيم

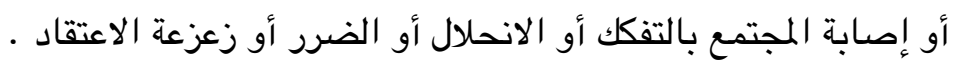
ع - لا يجوز إثارة الكراهية القومية والمذهبية وكل ما يؤدى إلى التحريض على التمييز

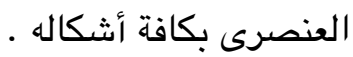


تاسعاً : مجلس حقوق الإنسـان التابع للأمم المتحدة (الدورة الثانية عشرة)

مارس ^ . . r ، إذ نص على : "وإذ تعترف بأن ممارسة الحق فى حرية الرأى والتعبير هى واحدة من الأسس الجوهريـة للمجتمع الديمقراطى... وإذ تدرك أيضـا أن الممارسة الفعلية للحق فى حريـة الرأى والتعبير هى مؤثثر مهم على مستوى حمـايـة حقوق الإنسـان والحريات الأخرى ، وإذ تضع فى اعتبارها أن جميع حقوق الإنسان عالمية

وغير قابلة للتجزئة ومترابطة ومتشابكة ..." .

\section{ثالثاً :القيود الدولية على حرية الرأى والتعبير}

بالرغم من شـمول كل المعاهدات والاتفاقات الدوليـة والإقليمية المتعلقة بحقوق الإنسان على بنود واضحة بشأن الحق فى حرية إبداء الرأى والتعبير ، إلا أنها أيضـا تضمنت

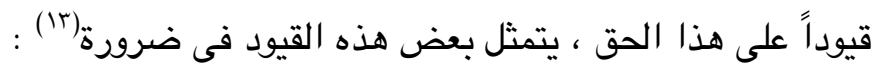

$$
\text { • احترام القوانين واللوائح المطبقة فى الدولة . }
$$

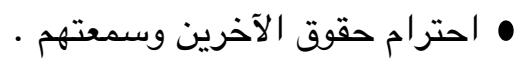

• حماية الأمن القومى والنظام العام والصـحة العامـة والآداب العامـة ومنع الجريمة

$$
\text { ومنع إفشاء الأسرار الخاصة . }
$$

$$
\text { • حماية الأخلاق والطفولة والمراهقة . }
$$

علدم التعرض لأى دعايـة للحـرب وأيـة دعـوة إلى الكراهيـة القوميـة أو العنصريـة

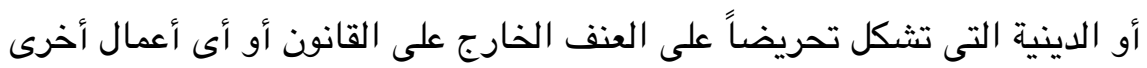

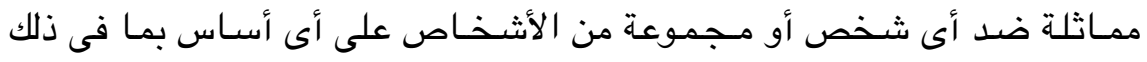
العرق أو اللون أو الدين أو اللغة أو المذهب الدينى ، وتعتبر جرائم يعاقب عليها القانون .

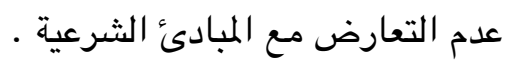

علدم التعرض للمقدسـات وكرامـة الأنبياء ، أو ممـارسـة كل مـا من شـأنه الإخلال بالقيم أو إصابة المجتمع بالتفكك أو الانحلال أو الضرر أو زعزعة الاعتقاد . 
ويذلك فإن القيود التى ترد على حريـة الرأى والتعبير ونصت عليها المواثيق والمعاهدات الدولية تشـمل القيود الأخلاقية والقيود المتعلقة بالنظام العام والمبادىئ

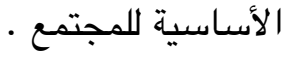

\section{رابعاً : حلدودونطاق حرية الرأى والتقبيرفى التشريعاتالوطنية}

التعبير عن الرأى هو العنصر الأساسى فى هذا الحق الإنسانى ، ويشمل كما أوضحنا

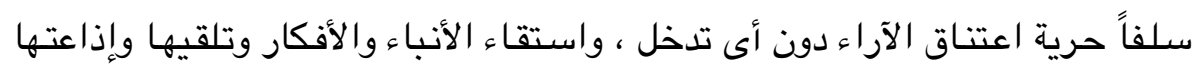
بأية وسيلة كانت دون تقيد بالحدود الجغرافية .

وبذلك فإن للإنسـان أن يبدى رأيه فيما يعن له من موضسوعات أو غير ذلك وفى حدود القانون وعدم التعرض لحريـات الغير وحقوقهم ، وهنا يحدث التداخل فى نطاق مشـروعيـة حريـة التعبير وإبـداء الرأى ، وبـين تعدى هـذا النطاق والوقوع فى براثن المخالفة القانونية التى تستوجب العقاب .

فعندما يبدى شخص رأياً فى موضوع معين أو شخص معين أو يمارس نقداً فقد يتهم بالقذف أو السب أو التحريض أو الإهـانـة ... إلخ ، ممـا يـوقعه فى طـائلة العقاب الجنائى ، هـذه التهم قد يستخدمها (فى بعض الأحيان) أصـحاب المصلحة والحكومات لتكميم الأفواه وقتل حرية الرأى والتعبير ، وفى الجهة المقابلة ، قد يتخطى من يبدى الرأى نطاق وحدود حريته فى إبـاء الرأى والتعبير بحجة الحق فى ممارسة هذه الحريـة ليتعرض لأشخاص (طبيعية أو معنوية) بفاحش القول وكذبه وعلدم صحته وبـأمور تنطوى تحت مسـى السب والقذف والإهـانـة مما يتسبب في إيذاء الآخرين والتعدى على حريتهم وحقوقهم الإنسانية ، كمـا قد يستخدم الحق فـى إبـداء الرأى كـ أو التعبير للتحريض وإحداث الفتن ، كمـا قد يستخدم حرية إبداء الرأى والتعبير فى مخالفة الآداب العـامة أو النظام العام أو التعدى على هيبة الدولة ورموزهـا مما يـد مخالفاً للقوانين الدولية والوطنية . 
وهى أمور نرفضها جملة وتفصيلاً تصديقا لدينتا الحنيف وشريعتنا الإسلامية وحقوقنا الإنسانية وتوافقاً مع المواثيق الدولية فى هذا الثـأن ، والتى تمنع الجور على ولى حقوق الآخرين بحجة ممارسة الحرية فى إبداء الرأى أو التعبير عنه . ونتناول فى إيجاز بعض التشريعات الوطنية والتى أوردت حدود ونطاق حرية التعبير عن الرأى وما يخرج عن هذا النطاق :

فرنسـا : يمنـع القانـون الفرنسـى أى كتابـة أو حديـث علنـى مـن شـأنـه أن يـؤدى إلى حقد أو كراهية لأسبـاب عرقية أو دينية ، ويمنع أيضـا نشـر أفكار الكراهية بسبب الميول الجنسية للفرد ، والتـخل المشـين والعدوانسى بمعتقـدات النـاس الخاصة .

ألمانيا : يتضمن القانون الأسـاسى الألمانى والذى يسمى Grundgesetz فى البند الخامس منه على الحق فى حرية الرأى والتعبير ، ولكنه يمنع خطابات الكراهية ضد العرق والدين والميول الجنسية إضـافة إلى منع استعمال الرموز النازية مثل الصليب المعقوف . الولايات المتحدة الأمريكية : وضعت المحكمة العليا مقياساً لما يمكن اعتباره إساءة أو خرقاً لحدود حرية التعبير ويسمى باختبار ميلر Miller test حيث بدأ العمل به فى عام سV 19 ويعتمد المقياس على ثلاثة مبادئ رئيسة ، هى : > رؤية غالبية الأشخاص فى المجتمع طريقة التعبير مقبولة أم لا . > إذا كانت طريقة إبداء الرأى تعارض القوانين الجنائية للولاية أم لا . > طريقة عرض الرأى وهل تتحلى بصفات فنية أو أدبية جادة أم لا . 


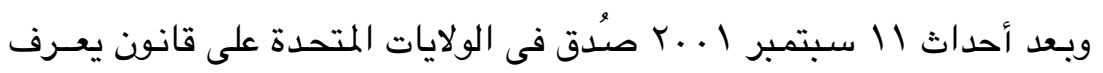

بـ Patriot Act الذى منح الأجهزة الأمنية صلاحيات واسعة تمكنها من القيام بأعمال تنصت ومراقبة وتفتيش دون اللجوء إلى التسلسل القضائى الذـى كان متبعـا قبـل

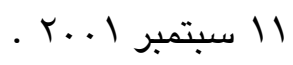

المملكة العربية السعودية : احتلت حقوق الإنسـان فى المملكة مكانة مهمة اهتداء بديننا الإسـلامى وما تقره الشريعة الإسلامية ، ولعل حرية التعبير عن الرأى من الحريات التى اهتمت بها الأنظمة الداخلية فى المملكة ، فنجد المادة (^) من النظام الأسـاسى للحكم تنص على أن الحكم فى المملكة العربية السعودية يقوم على : "أساس العدل والشورى والمسـاواة وفق الشـريعة الإسلامية" ، ونصت المادة (rع) منه على أن : "مـجلس الملك ومجلس ولى العهد مفتوحسان لكل مواطن ولكل من له شكوى أو مظلمـة ، ومن حق كل فرد مخاطبة السلطـات العامة فيما يعرض له من

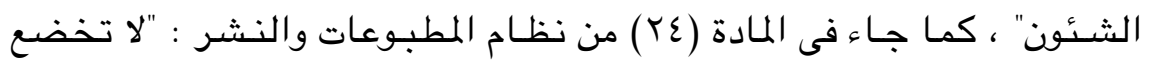
الصحف المحلية للرقابة ، إلا فى الظروف الاستثنائية التى يقرها رئيس مجلس

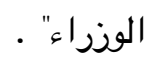

• جمهورية مصر العربية : حرص الدستور المصرى على كفالة حرية الرأى والتعبير ، فنص فى المادة Vع منه على : "حرية الرأى مكفولة ولكل إنسـان التعبير عن رأيه ونشـره بـالقول أو الكتابـة أو التصـوير أو غير ذلك من وسـائل التعبير فى حدود القانون ، والنقد الذاتى والنقد البناء ضمان لسلامة البناء الوطنى" . وبذلك حدد الدستور المصرى نطاق التعبير عن الرأى وحدوده التى ينظمها القانون ، وأباح النقد الذاتى والبناء لما ينطوى على حرص على سلامـة المجتمع وتقويم

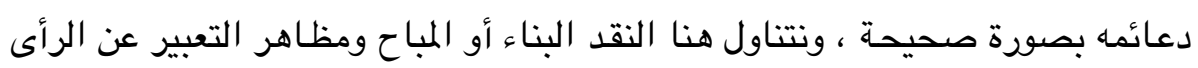


الذى يخرج عن نطاق حرية الرأى ويقع تحت طائلة قانون العقوبات المصرى ، وذلك

\section{1- النقد المباحكأحدأنواع حرية/الرأىوالتعبير}

يستند حق النقد إلى ما ورد من نصوص فى الدساتير والمواثيق الدولية التى تمنح الفرد حرية التعبير وإبداء الرأى ، ويقصد به إبداء الرأى فى أمر من الأمور أو عمل ما

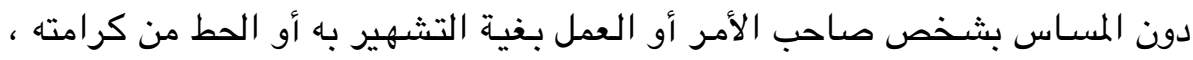

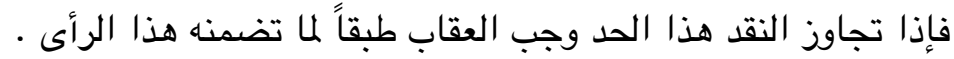
فالهدف الأسـاسى من النقد كشف أمر من الأمسو يهم الرأى العام ويعلى المصلحة العامة ويقوم المجتمع والقائمين عليه ، وهو حق يستعمله الإنسان دون مسئولية ما دام فى نطاق الحدود التى رسمها الدستور والقانون ، مع وجوب توافر

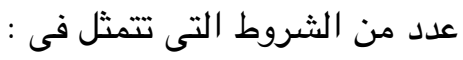

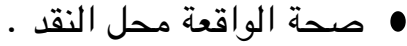

• أن يقوم صاحب النقد باتخاذ التحرى والتبت الواجبين للتاكد من صحة الواقعة .

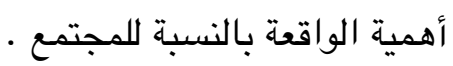

هياغة وإعلان النقد بشكل ملائم تراعى فيه الجوانب القانونية والأخلاقية .

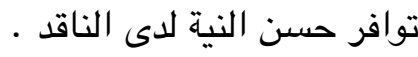
أن يكن النقد بهدف المصلحة العامة للوطن والمجتمع . لماك.

\section{r - صورالتعبيرعن الرأىالتى تخرجمن نطاقوحدود الجقى في حرية/الرأىوالتعبيرطبقاً لقانوز

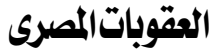

كما يتمتع الإنسان بحق حرية الرأى والتعبير فإن هناك قيوداً تحد من هذا الحق ، هذه القيود قد تكون شرعية أو أخلاقية أو قانونية أو تتعلق بالنظام العام والمبادئ الأساسية 
للدولة ، فـإذا خـرج التعبير عن الرأى عن نطاقـه المشـروع وانحرف ليمس الأفراد أو الآداب العامة أو شئون البلاد أدى إلى وقوع صاحبه تحت طائلة القانون . ومن الصور التى تعد قيوداً على التمتع بـحرية الرأى والتعبير وتؤدى إلى إلى التعدى على حقوق الآخرين وحرياتهم :

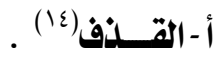

القذف لفة يعنى الرمسى (رمسى - يرمسى - رميـاً) ويشمـل الرمسى بالسهـم أو الحصى

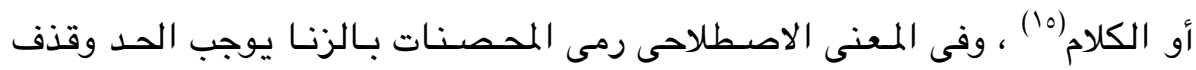
المحصنة أى رماها بريبة .

وعرف الفقه الفرنسى القذف بـأنه الادعاء أو الاتهام علناً بواقعة محددة تمس بـأه شـرف أو اعتبار الشخص المنسوب له هذه الواقعة ، وتعد مسـاساً بـالشـرف ومخالفة لقانون الأخلاق ويعرض فاعلها للاحتقار ، أمـا الفقه الإنجليزى فقد عرف القذف بأنه إسناد أو أخبار عن واقعة معينة من شأنها تعريض المجنى عليه للعقوبات المقررة قانوناً أو وجوب احتقاره عند أهل وطنه إن صحت . أما قانون العقويات المصرى فقد تصدى للقذف فى المادة ؟ .r منه التى نصت على : "يعد قاذفاً كل من أسند لغيره بواسطة إحدى الطرق المبينة بالمادة IVI من هذا القانون أموراً لو كانت صـادقة لأوجبت عقاب من أسندت إليه بالعقوبـات المقررة لذلك قانوناً أو أوجبت احتقاره عند أهـل وطنـه ، ومع ذلك فالطعن فى أعمـال موظف عام أو شـص ذى صفة نيابية عامـة أو مكلف بخدمـة عامـة لا يدخل تحت حكم الفقرة السـابقة إذا حصل بسلامـة نية وكان لا يتعدى أعمال الوظيفة أو النيابـة أو الخدمة العامـة ويشرط أن يثبت مرتكب الجريمـة حقيقة كل فعل أسند إليه ولا يغنى عن ذلك اعتقاده صحة هذا الفعل ، ولا يقبل من القاذف إقامة الدليل لإثبات ما قذف به إلا فى 


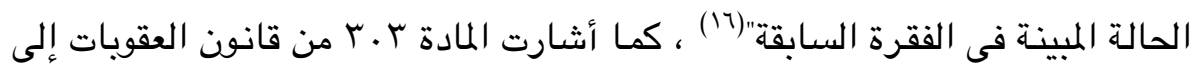
أنه : "فإذا وقع القذف فى حق موظف عام أو شخص ذى صفة نيابية عامة أو مكلف بخدمة عامة ، وكان ذلك بسبب أداء الوظيفة أو النيابة أو الخدمة العامة ، كانت العقوية الحبس مدة لا تجاوز سنتين وغرامة لا تقل عن خمسـة آلاف جنيه ولا تزيد على عشرة آلاف جنيه أو إحدى هـاتين العقويتينتج ، أمـا المادة 9 . ب فتنص على : "لا تسرى

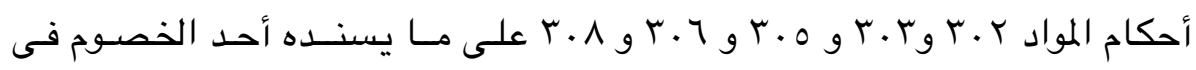

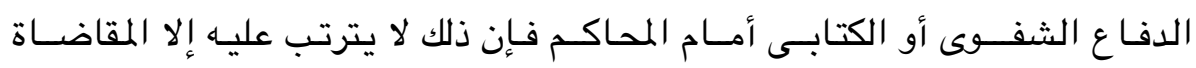
الملنيـة أو المحاكمة التأدييـة ... ويحكم فى جميع الأحوال بمصادرة الأجهزة وغيرها مما يكون قد استخدم فى الجريمــة أو تحصـل عنهـا كمـا يحكم بمحسو التسـيـلات

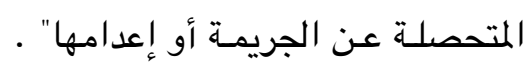
ومما سبق نجد أن هناك شروطاً لاعتبار مـا أبداه الشخص من رأى يعد قذفاً

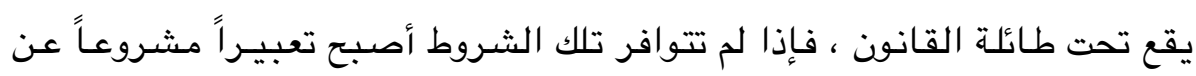
الرأى ، ومن تلك الثروط : الث

ه أن يتم نسبة أمر مـا إلى شخص معـين ، سواء كان نسبته لهذا الشخص بصفة تأكيدية أو غير ذلك ، وبأى طريقة للتعبير تعطى المعنى وتوضحه ، أو يكون هذا

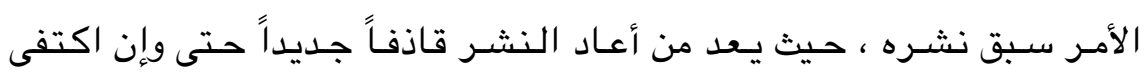
بالإشـارة إلى هذا الموضسوع دون الخوض فيه لأن ذلك يعد إعادة للتذكير بوقائع وموضوع القذف .

ه أن يكون موضوع الواقعة محدداً ومعيناً وارتكابه أو فعله يخضع فاعله لقانون العقوبات لو صحت حقيقته ، أى أن يكون الفعل موضوع القذف مؤثماً قانوناً ، وأن يؤدى إلى احتقار مرتكبه عند أهل وطنه . 
تحقق العلانية بأى طريقة أو وسيلة مما وردت فى المادة IVI من قانون العقويات .

توفر القصد الجنائى لدى القاذف ، بـأن يكون القاذف متعمداً وتتجه إرادته إلى لى

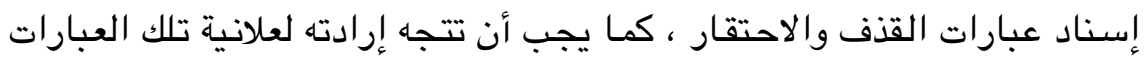

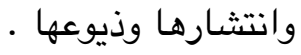

وبالتالى فإن عدم توافر الشروط الأربعة السابقة ، لا يجعل العبارات التى يدلى ولى

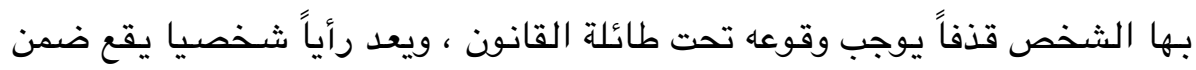

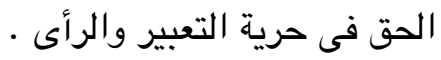

كما نثير هنا إلى أن المثرع أباح إبداء الرأى والتعبير استعمالاً لحق الإنسان

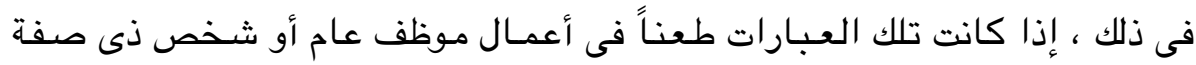

نيابية عامة أو مكلف بخدمة عامة ، مع شرط توافر سلامة نيته وكان لا يتعدى أعمال

الوظيفة أو النيابة أو الخدمة العامة وبشرط أن يثبت مرتكب الجريمة حقيقة كل فعل أسند إليه ولا يغنى عن ذلك اعتقاده صحة هذا الفعل ، أو كانت تلك العبارات صادرة من أحد الخصوم فى الدفاع الشفوى أو المكتوب أمام المحاكم ويترتب على ذلك فقط

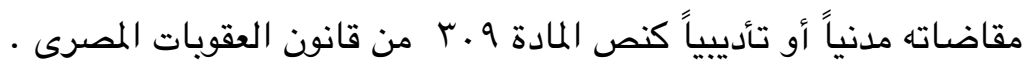

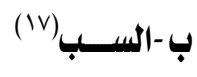

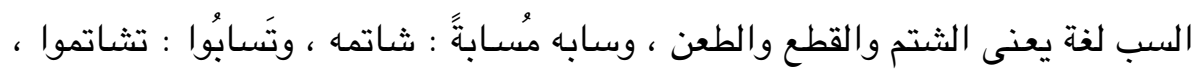
(والتساب) التشاتم والتقاطع ، وهذا سبة عليه بالضم أى عار يسب به ، ورجل سبة

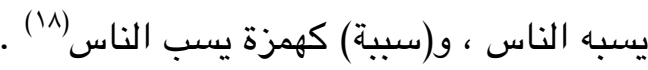

والسب تعبير مهين للكرامة وخدش للحياء والتحقير ، ونصت عليه المادة T. T.

من قانون العقوبات المصرى : "كل سب لا يشتمل على إسناد واقعة معينة بل يتضمن

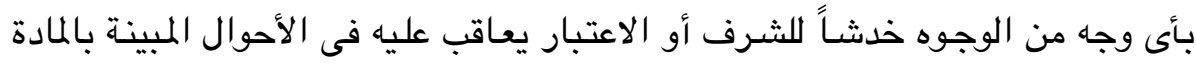


IVI بالحبس مدة لا تتجاوز سنة ويـرامـة لا تقل عن ألف جنيه ولا تزيد على خمسة آلاف جنيه أو بإحدى هاتين العقويتين" ، وبالتالى فإن التعبير عن الرأى يعد سباً إذا توافر فيه خدش للشرف أو الاعتبار بأى وجه كان مما يمس بكرامة الإنسان عند نفسه أو يـحط من شـأنه لدى الآخرين مع الوضع فى الاعتبار عدم إسـناد هـذه العبارات (السب) إلى واقعة معينة (كما في القذف) ، كأن ينسب للإنسـان السرقـة أو الرشـوة أو الاختلاس ، على أن يتوافر ركن العلانية والتعمد أو العلم والإرادة ، أمـا إذا كان السب موجهاً لموظف عام أو شخص ذى صفـة نيابية عامـة أو مكلف بخدمـة عامـة

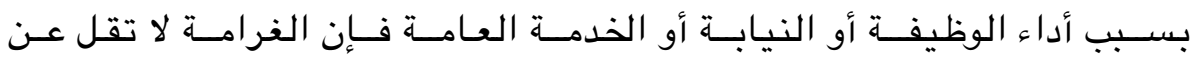

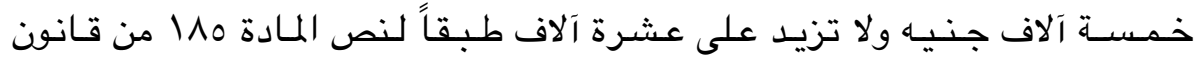

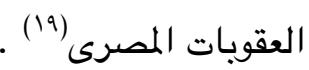

ولم يترك المشرع النص على التعرض بالسب للهيئات المهمة فى الدولة ، فذكر فى المادة ع^\ا النص على : "يعاقب بالحبس ويغرامسة لا تقل عن خمسة آلاف جنيه ولا تزيد على عشرة آلاف جنيه أو بإحدى هاتين العقويتين كل من أهان أو سب بإحدى الطرق المتقدم ذكرها مجلس الثعب أو مجلس الشورى أو غيره من الهيئات النظامية أو الجيش أو المحاكم أو السلطات أو المصالح العامة" .

\section{ج- التحريض}

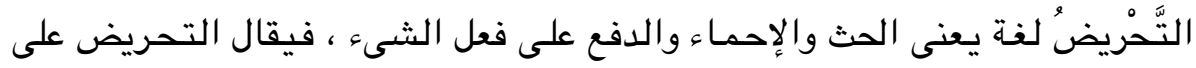

$$
\text { القتال الحث والإحماء عليه(·r) }
$$

وقد تتاول قانون العقويات التحريض فى المواد ع I أ ، IVo ، IV ، IVY ،

(YI) IVV ، IVY حيث أوضـحت هـذه المـواد صـور التحـريض والعقـوبـات الواجب

$$
\text { تطبيقها ، ومن هذه الصور : }
$$


التحريض على ارتكاب جريمـة من الجرائم المبيـنـة فى المـادة عبا من قانون

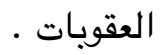

التحريض على ارتكاب جنايات القتل أو النهب أو الحرق أو جنايات مخلة بأمن

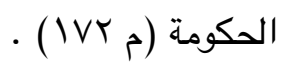

تحريض موظف أو مستخدم عام على ترك العمل أو الامتناع عن تأدية واجب من

$$
\text { واجبات الوظيفة . }
$$

التحريض على قلب نظـام الحكومـة المقرر فى القطر المصرى أو على كراهته

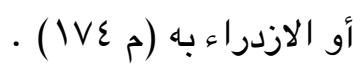

تحبيذ أو ترويج المذاهب التى ترمى إلى تغيير مبادئ الدستور الأساسية أو النظم

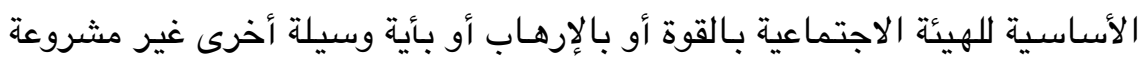

$$
\text { . ( IV } \left.\varepsilon^{2}\right)
$$

• تحريض الجند على الخروج عن الطاعة أو إلى التحول عن أداءواجباتهم العسكرية

$$
\text { . ( }\left(\mathrm{l}_{0} \mathrm{O}^{\circ}\right)
$$

التحريض على بغض طائفة أو طوائف من الناس أو على الازدراء بها إذا كان من

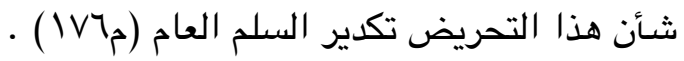

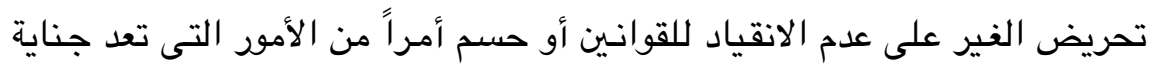

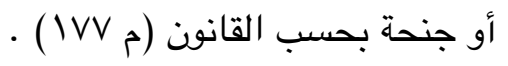

فإذا مـا تضمن التعبير عن الرأى إحدى الصور السابقة عد تحريضاً يعاقب

عليه القانون ، وهو أمر منطقى حيث إن جميع هذه الصور تحدث خللاً بالنظام العام وتحدث الفرقة والخلاف والكراهية وتقويض دعائم الدولة واستقرارهـا ، الأمر الذى الذى يجب أن يقابل بالقانون حفاظاً على المجتمع وتماسكه واستقراره ـ . 


\section{دـ - العيبوالإهانة}

الإهانة وفقاً لأحكام محكمة النقض يقصـــ بها العبـارات التى تحمـل معنى الإساءة أو المساس بـالثـور ، وتشـمل أيضًا كل فعل أو قول يمس بـالهيبة والكرامـة ويقلل من احترام الغير وتقدير الناس ، وهى أوسع دلالة من القذف والسب .

أمـا فى قانون العقويـات المصرى ، فقد تضمنت عدد من المواد صور وأشكال

هذه المخالفة التى تخرج بصاحبها من نطاق حريـة الرأى والتعبير لتضعه تحت طائلة القانون(rr) ، حيث يتضـح ممـا ورد بتلك المواد أنها تنصسب على موظفين عموميين أو هيئات عمومية أو أجنيية ، وذلك كما يلى : • إهانة رئيس الجمهورية بإحدى الصور الواردة فى المواد (IVA - IVI) . • إهانة أو سب مجلس الشعب أو مجلس الثــورى أو غيـره مـن الهيئـات النظاميـة

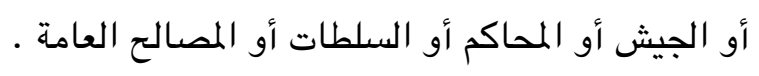
الإخلال بمقام قاض أو هييته أو سلطته فى صدد دعوى . • القدح أو الذم فى الحكومـة أو القانون أو قرار جمهورى أو أى أعمال لجهة الإدارة العمومية إذا صدر من شخص وإن كان من رجال الدين أثناء تأدية وظيفته . العيب أو الإهانة للطعن فى عرض الأفراد أو خدش لسمعة العائلات .

\section{هـ - مخالفة الآدابالعامة}

إذا كان النظـام العام هـو مـمـوعة المبادئ الأسـاسـية (السـياسـية والاقتصـادية

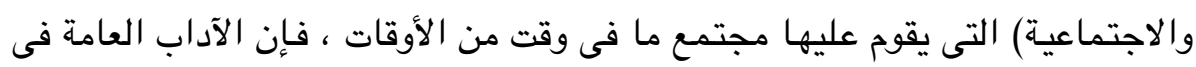
لغة القانون هـى مجموعة المبادئ النابعة من المعتقدات الدينيـة والأخلاقية المتوارثة

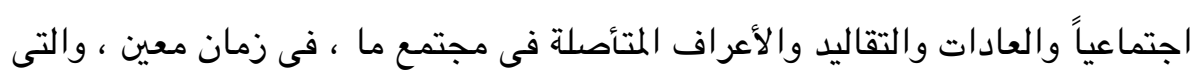

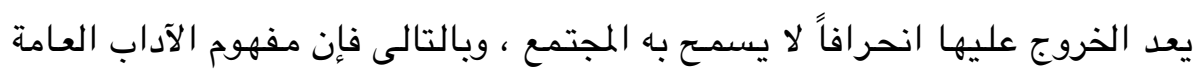
يرتبط بشقين أساسيين هما (rr) : 
المكان : فالآداب العامة بحكم كونها جزءاً من النظام العام وترتبط بالبيئة المحيطة

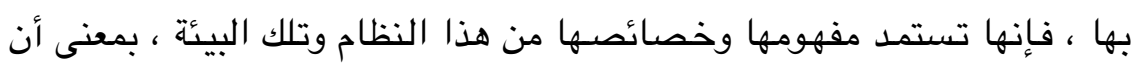

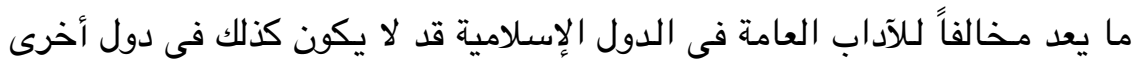

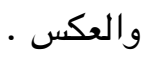
الزمان : كما ترتبط قواعد وخصائص ومفهوم الآداب العامة بالمكان ترتبط أيضا

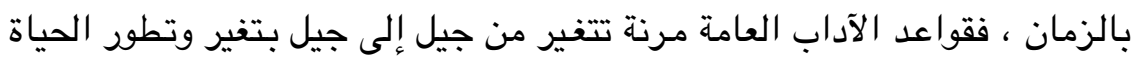

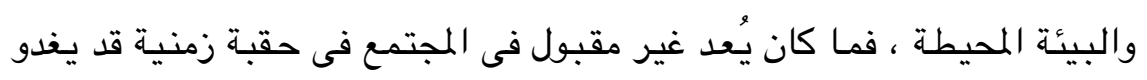

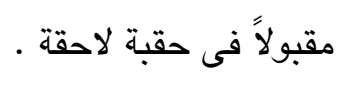
وقد تكون قواعد الآداب العامة تتعلق على وجه الخصوص بتلك المبادئ والأسس المتصلة بالأمور الجنسية ، بيد أنها تشمل كذلك بعض المسائل الأخرى كالمقامرة

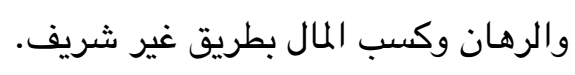

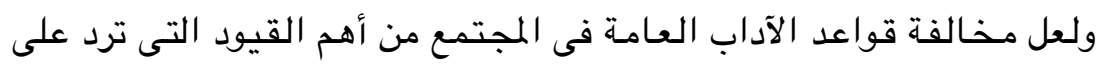

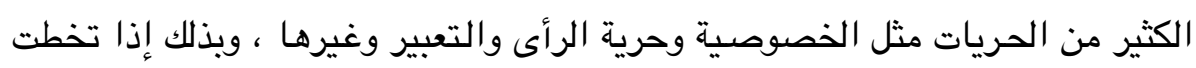

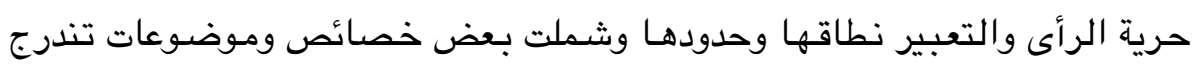
تحت مخالفة الآداب العامـة ، أصبحت مخالفة للنظام العام وتقع تحت طائلة القانون

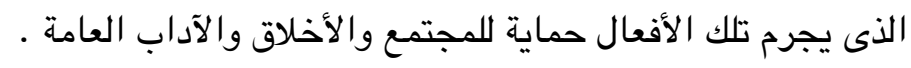
ويتضمن قانون العقوبات المصرى العديد من المواد التى تنص على تجريم هذا

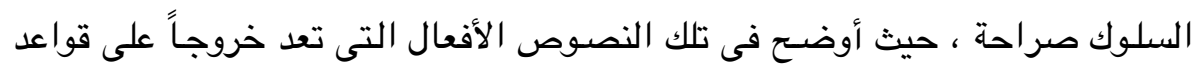

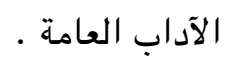

فقد ورد بالمادة IVN : "يعاقب بالحبس مدة لا تزيد على سنتين وبغرامة لا تقل عن خمسة آلاف جنيه ولا تزيد على عشرة آلاف جنيه أو بإحسى هاتين العقويتين كل

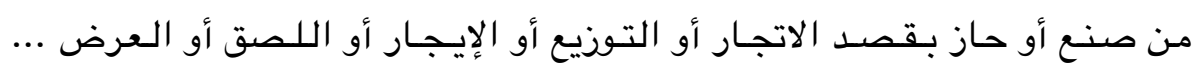




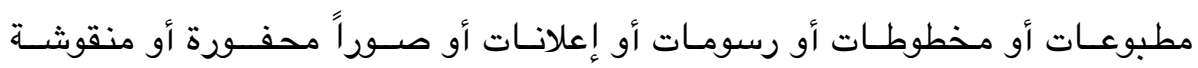
أو رسومات يدويـة أو فوتوغرافيـة أو إشـارات رمزية أو غير ذلك من الأشياء أو الصور عامة إذا كانت منافية للآداب العامة" .

\section{و - إشاعة أوترويج أونشرأخباركاذبة}

يعد نثـر وتداول الأخبار وإبداء الرأى والتعبير أحد الحقوق التى يمارسـها الإنسان والتى تسـهم في المـشـاركة فى الحيـاة العـامـة والعمل العام والنواحى السيـاسية والاقتصادية والاجتماعية ، بيد أن نثر تلك الأخبار وتداولها كأحد أنواع حرية الرأى والتعبير لم تُرك حرة مطلقة ، بل قيدت بحدود المصلحة العامة ، والبعد عن الأخبار الكاذبـة التى قد تتسبب فى مشكلات وقلاقل داخلية ، كمـا أن تلك الأخبار الكاذبـة قد تسئ للدولة أمـام المجتمع العالمى ممـا يلحق بها الضرر ، كل هذه الصسور تؤدى إلى لى الانحراف عن نطاق حرية الرأى والتعبير ، ويضعها تحت طائلة القانون الذى يؤثث تلك الأفعال .

وبذلك نجد أن نشر وترويج الأخبار الكاذبة أو تلك التى تضر بسمعة الدولة والنظام العام والسكينة أو تهدف إلى خلق الفتنة تخرج عن نطاق حرية الرأى والتعبير وذلك طبقاً للمواثيق الدولية والقوانين الوطنية التى تهدف دومًا إلى الحفاظ على سلامة الوطن وحمايته . - الوكن

وقد تناول قانون العقوبات المصرى تلك الصور غير المشروعة للخروج عن نطاق

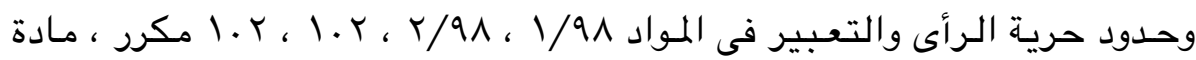

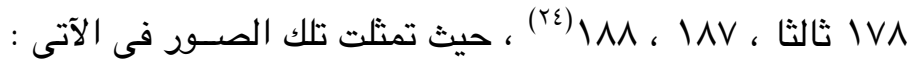
الترويج أو التحبيذ (مع استغلال النزعة الدينية) بالقول أو بالكتابة أو بأية وسيلة أخرى لأفكار متطرفة بقصد إثارة الفتنة أو تحقير أو ازدراء أحد الأديان السماوية أو الطوائف المنتمية إليها أو الإضرار بالوحدة الوطنية أو السلم الاجتماعى • 
الترويج بأية طريقة من الطرق لتغيير مبادئ الدستور الأساسية أو النظم الأساسية

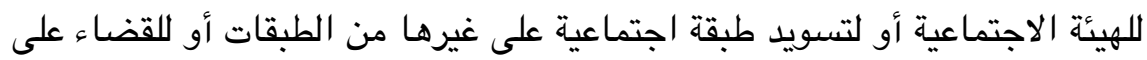

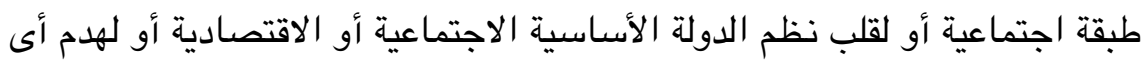
نظام من النظم الأسـاسية للهيئة الاجتماعية متى كان استعمال القوة أو الإرهـاب أو أية وسيلة أخرى غير مشروعة ملحوظاً فى ذلك .

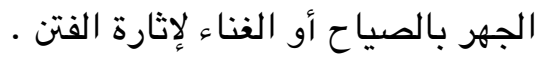

إذاعة (عمداً) أخبار أو بيانات أو إثـاعات كاذبة أو مغرضـة أو بث دعايات مثيرة إذا كان من شأن ذلك تكدير الأمن العام أو إلقاء الرعب بين الناس أو إلحاق الضرر بالمصلحة العامة ، وتشدد العقوبة إذا حدثت فى زمن الحرب . الإسـاءة إلى سمعة البلاد بصنع أو بتوزيع أو بلصق أو بعرض صور سواء أكان ذلك بمخالفة الحقيقـة أو بإعطاء وصف غير صحيـح أو بإبراز مظاهـر غير لائقة

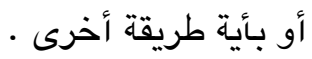

نشر أمور من شأنها التأثير فى القضاة الذين يناط بهم الفصل فى دعوى مطروحة

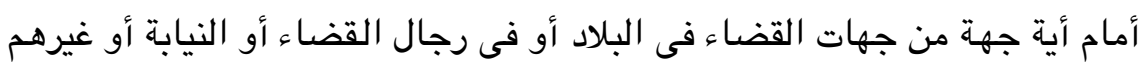

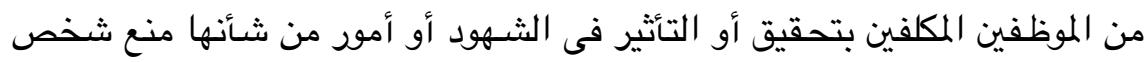

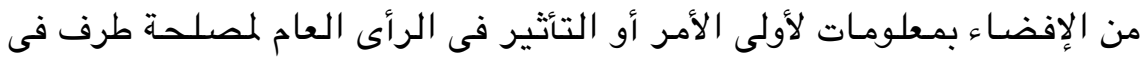

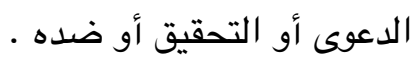

نشر بسوء قصد بإحدى الطرق المتقدم ذكرهـا أخبار أو بيانات أو إشـاعات كاذبـة

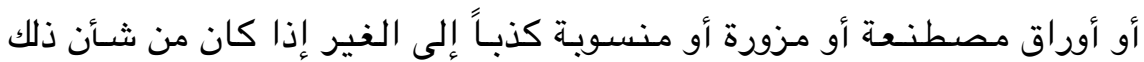

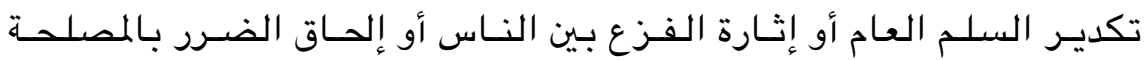
العامـة . 
تعد حرية الصحافة مؤثراً مهمة لحرية التعبير عن الرأى ، حيث تكفل المواثيق الدولية

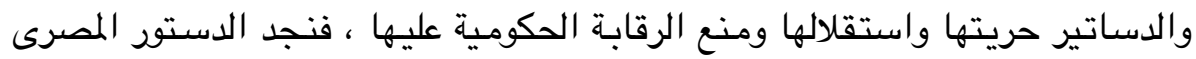

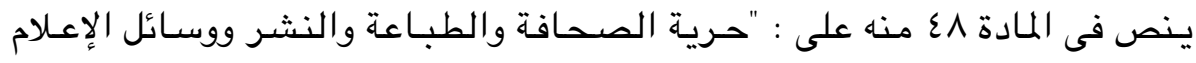

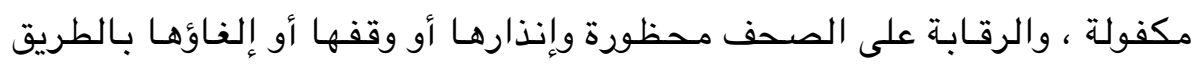

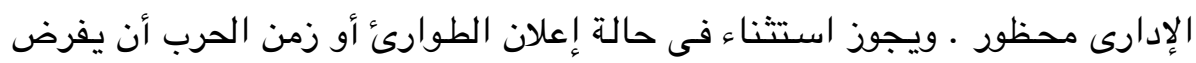

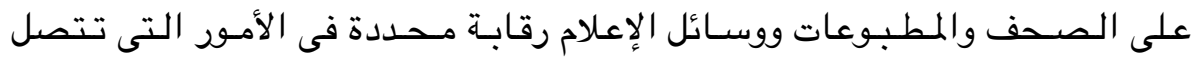

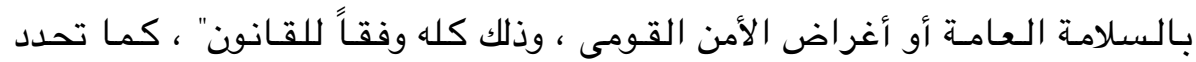

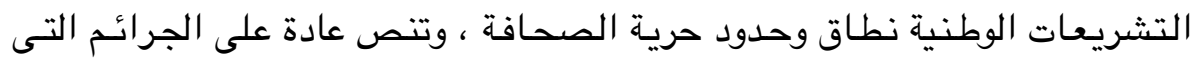
تتعلق بالصحف ، فنجد أن قانون سلطة الصحافة المصرى رقم 97 لسنة 1997 يختص المجلس الأعلى للصحافة بسلطة إصدار التراخيص للصحف ، كما يمنح قانون

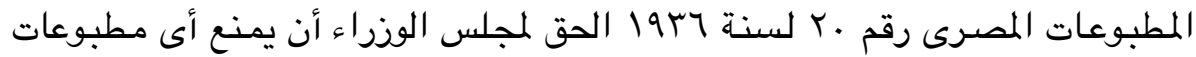

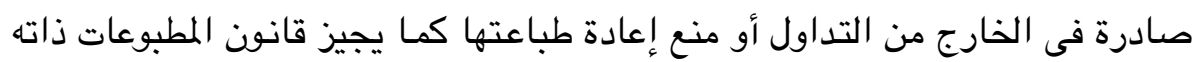

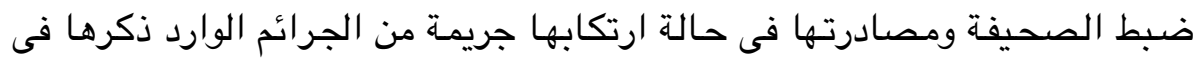
الكتاب الثانى من قانون العقوبات الخاص بجرائم الجنايات والجنح التى تقع بواسطة

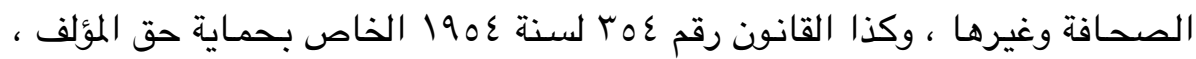

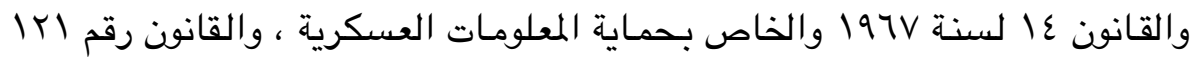

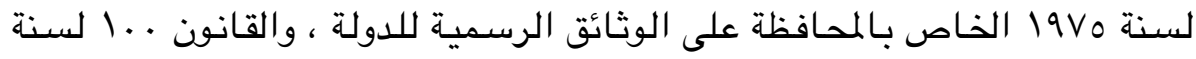

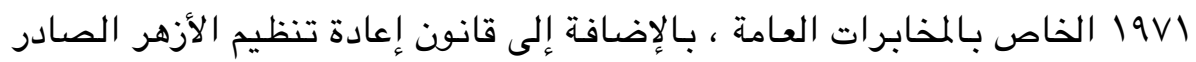

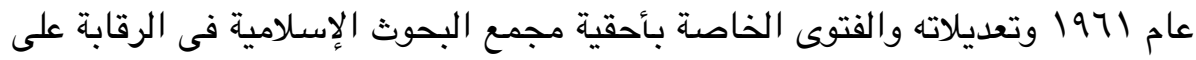

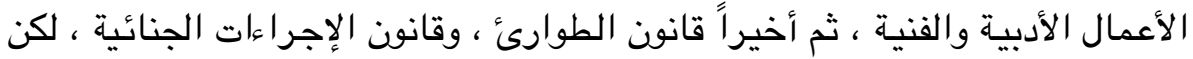

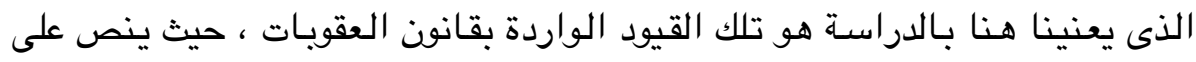

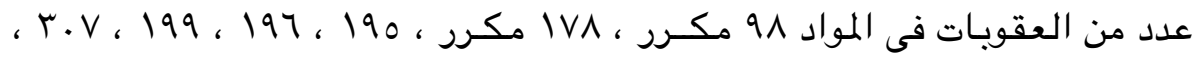

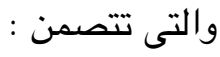


مسئولية رؤساء التحرير والناشرين بصفتهم فاعلين أصليين بمجرد النشر إذا ارتكبت الجرائم المنصوص عليها فى المواد MM ، IVV عن طريق الصحف ، كما يعاقب بصفتهم فاعلين أصليين الطابعون والعارضون والموزعون ، ويجوز معاقبة

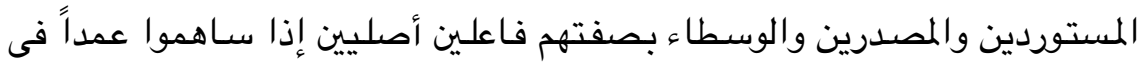
ارتكاب الجنح المنصوص عليها فى المادة السابقة متى وقعت بطريق الصحافة ، ولم يتم التوصل لمعرفة مرتكب الجريمة (المادة IVA مكرر) . مسئولية كل من حاز بالذات أو بالواسطة أو أحرز محررات أو مطبوعات تتضمن

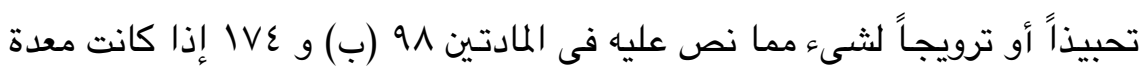
للتوزيع أو لإطلاع الغير عليها (المادة 91 مكرر) . معاقبة رئيس تحرير الجريدة أو المحرر المسئول عن النشر بصفته الفاعل الأصلى لإعلى عن الجرائم التى ترتكب بواسطة صحيفته ، مع عدم الإخلال بالمسئولية الجنائية بالنسبة لمؤلف الكتابة أو واضع الرسم أو غير ذلك (المادة 190) ـ

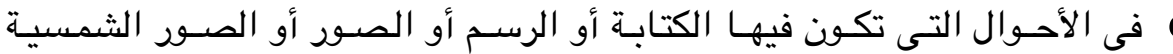

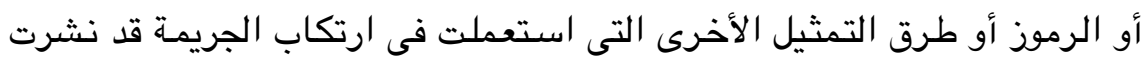

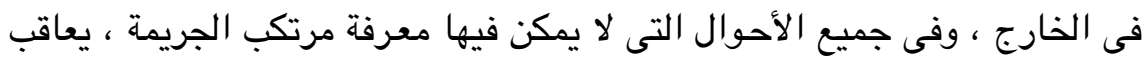
بصفتهم فاعلين أصليين ، المستوردون والطابعون ، فإن تعذر ذلك يعاقب البائعون

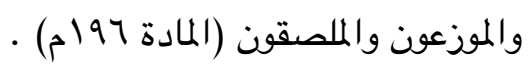
تعطيل الجريدة إذا ارتكبت جريمة من الجرائم المنصوص عليها فى المواد السابقة بطريق النشر فى إحدى الجرائد واستمرت الجريدة أثناء التحقيق على نثر مادة من نوع ما يجرى التحقيق من أجله أو من نوع يثبهه (المادة 199 ) .

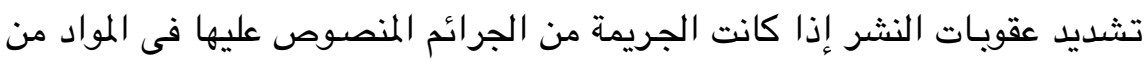

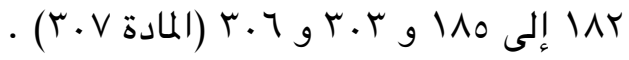




\section{خامساً :حرية|الرأىوالتعبيرفىييئة|لإنترنت}

مما لا شك فيه أن الإنترنت يعد الوسيلة الأقوى والأكبر استخداماً للتعبير عن الرأى وممارسـة الإنسان لحقوقه وحرياته نظراً لعالمية تلك الثبكة ولا مركزيتها وبعدها عن سيطرة الحكومات والدول (إلى حد مـا) ، هذه العالمية والانتشار التى تتميز بها شبكة الإنترنت استطاعت أن تجعل كل مشترك أو مستخدم متصل بـالإنترنت الولوج لأى لـى موقع إلكترونى ليدلى برأيه ويعبر عن أفكاره كمـا يشاء ، بل يمكن أن ينشـى مـوقعاً أو منتديات أو صفحات للتحاور وتبادل الأفكار والآراء فى جميع المجالات مع الآخرين ، وبالتالى أصبح الإنترنت الوسيلة أو الواسطـة أو النـافذة الإعلامية الأكثر حريـة وانتشارا وذيوعاً وتفاعلية .

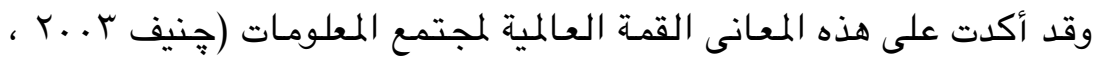

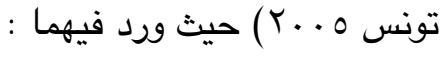

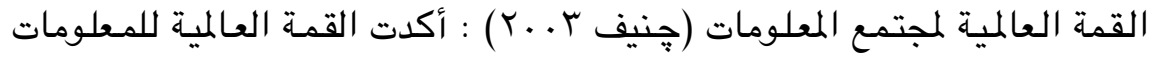
r. . r ، فى إعلان المبادئ على عالمية كل حقوق الإنسـان والحريات الأساسية وعدم قابليتها للتجزئة (الفقرة الثالثة) ، كمـا نصـت فـى الفقرة الرابعة من المبادئ على أن : "ونؤكد من جديد كأسـاس جوهـرى لمجتمع المعلومـات ، أن لكل فرد الحق فى حريــة الرأى والتعبيـر كما ورد فى المادة 19 من الإعـلان العالمـى لحقوق الإنسان

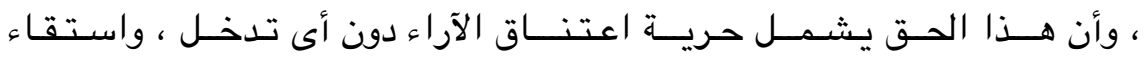
المـعلومـات والأفكار وتلقيهـا وإذاعتهـا بـأى وسيلة كانت دون تقيــــ بالحــدود

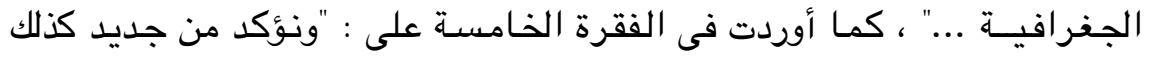
التزامنـا بأحكام المادة وج من الإعلان العالمى لحقوق الإنسان والذى ينص على أن على كل فرد واجبات نحو المجتمع الذى يتاح فيه وحده نمو شخصيته نمواً حراً كاملاً ، وأن الفرد لا يخضع فى ممارسـة حقوقه وحريـاته لأى قيود إلا مـا يقرره 
القانون لضمان الاعتراف بحقوق الغير وحرياته واحترامه ولتحقيق المقتضيات

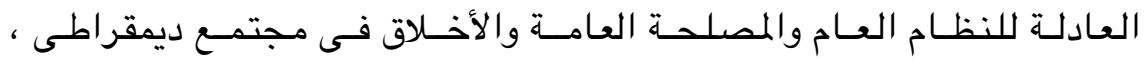

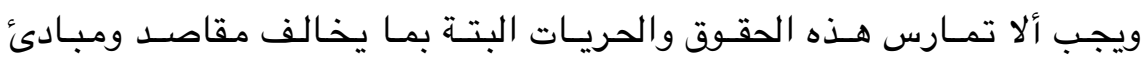

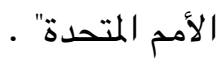

كما ورد في الفقرة رقم 0ه النص على : "نؤكد من جديد التزامنا بمبادئ حرية الصحافة وحرية المعلومات ... ومن الأمور المهمة فى مجتمع المعلومات حرية التماس

المعلومات وتلقيها وإذاعتها واستعمالها لأحداث وتراكم ونشر المعرفة" . القمة العالمية لمجتمع المعلومات (تونس ه . . ب) : أكدت القمـة الدعم الثابت لما ورد بالقمة العالمية للمعلومـات فى مرحلتها الأولى (جينيف r . .r) ، حيث نصت فى الفقرة الرابعة على : "نؤكد من جديد على الفقرات ع ، 0 ، 00 من إعلان مبادئ جنيف ، ونـعترف بأن حريـة التعبير وحرية تدفق المعلومـات والمعارف والأفكار أساسية فى مجتمع المعلومات ، وأن هذه الحريات تعود بالنفع على التنمية" . بيد أن القوة التى منحها الإنترنت لحق إبداء الرأى والتعبير لم تستخدم فقط فى ممارسة هذا الحق فى النطاق والحدود التى نظمتها ونصت عليها المواثيق الدولية(ro) ، بل تخطت ذلك إلى الجوانب السلبية التى تتعدى فيها نطاق حرية الرأى والتعبير سواء كان ذلك قد تم دون قصد أو بجهل من ارتكبها بالقوانين واللوائح ، أو تم بقصد ونية مؤكدة ، ليصبح الإنترنت ممراً آمناً لنشر المواد المخالفة للقانون والمسيئة والمتشددة والتى تخالف النظام العام والعقيدة داخل المجتمعات ، وكذا تتعدى على حقوق الغير ومنها حقوق الملكية الفكريـة والخصوصية وغيرهـا من الجرائم التى تقع عبر شبكة الإنترنت .

ومع هذا الجدل بين ما يدخل ضمن نطاق وحدود حرية الرأى والتعبير وبين ما يخرج عنها ، دار الصراع من أجل حريـة الرأى والتعبير ، وأصبح الإنترنت سـاحة 
للمعارك بـين المنادين بـإطلاق حريـة الرأى والتعبير وبـين ما يرون فى مصـالح الدولة وسلامتها وأمنها وأمن المجتمع مـا يوجب تشديد القيود على نطاق وحدود حرية الرأى والتعبير على شبكة الإنترنت لما تتميز بـه مـن خصائص تجعل مـن الصعوبـة احتواء أو تقييد أو توجيه ما يبث عليها ، الأمر الذى قد يؤدى فى بعض الأحيان إلى تشويه

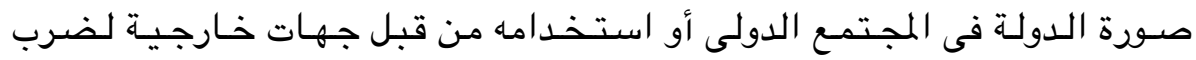
الاستقرار ونشر الأخبار الكاذبة وتصعيد الفتن والتحريض عليها . وقد يكون الانتشار والذيوع التى تتميز به الشبكة العالمية للمعلومات (الإنترنت) هو أخطر ما فى الموضوع ، فقبل الإنترنت كانت الحكومات والدول تستطيع أن تتحكم فى التعبير عن الرأى داخل الدولة بالتحكم فى الوسـائل التى يمكن استخدمها فى نشر هذه الآراءوأيضا التحكم فى انتشـارها وذيوعها بين الناس ، كما كانت الدولة أيضا تتحكم فيمـا يدخل حدودهـا من وسائل تحمل معلومـات أو التحكم فى المعلومـات التى يمكن أن يتم تسريبها إلى الخارج ليطلع عليها العالم .

أما اليوم فان الخصائص التى يتميز بها الإنترنت تخرجه من نطاق سيطرة الحكومـات ، ويالتالى علدم قدرتها على تحجيم أو تقييد حرية التعبير عن الرأى ، لذا

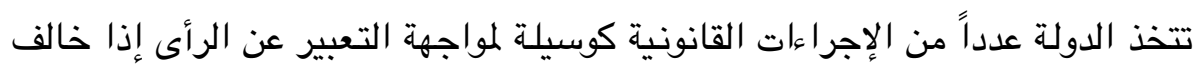
القانون أو إذا وجدت فيه ما يهدد كيانها أو يكثف خطاياهـا وأخطاءهـا أمام العالم ، ومح تطور التكنولوجيا توجهت تلك الدول لاستخدام وسائل تقنية لمواجهة حرية التعبير عن الرأى ومنها حجب المواقع وإغلاقها وتعطيلها أو قرصنتها .

\section{سادساً : أدواتمهارسة حرية|الرأىوالتعبيرفىبيئة|الإنترنت}

تتعدد الوسـائل التى يلجـاً إليها المستخدم فى بيئة الإنترنت ليمارس حريته فى التعبير عن رأيه ، ومن هذه الوسـائل الصحف الإلكترونيـة ، والمواقع والمنتـديات ، والنشـر الإلكترونى ، ورسـائل البريد الإلكترونى ، وسنتناول الصحف الإلكترونية كأحد أهم 
الوسائل للتعبير عن الرأى فى بيئة الإنترنت .

\section{الصحافة/الإكترونية|أو النسخ|الإكترونية|أو الصحافة|الرقمية}

لا شك أن الصحافة الإلكترونية التى تبث على شبكة الإنترنت وبخاصة التفاعلية منها

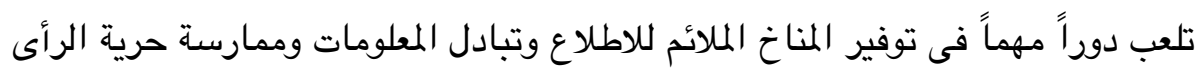
والتعبير - مان وقد نثأت الصحافة الإلكترونية فى منتصف السبعينيات عبر تقنية التليكست والفيديوتكس ، ولكنها لم تلق الاهتمام إلا فى ثمانينيات القرن الماضى مع التطورات التكنولوجية الحديثة وتنامى ظهور الشبكة العالمية للمعلومات (الإنترنت) ، حيث تم استخدامها كوسيلة إعلامية ضخمة تضاهى الوسائل الإعلامية المطبوعة والمرئية ، وتمنح للقارئ التفاعلية وإبداء الآراء فيما يكتب أو يبث على هذه المواقع ل

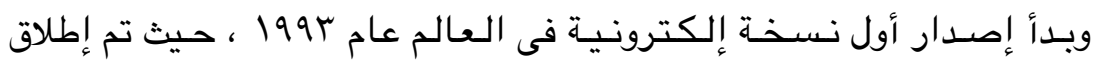
النسخة الإلكترونية لصحيفة سان جوزيه الأمريكية ، وفى عام ع199 أطلقت صحيفتا ديلى جراف والتايمز البريطانيتين النسخ الإلكترونية لهما ، أما بالنسبة للدول العربية فكانت صحيفة الثرق الأوسط وصحيفة إيلاف اللتان يتم إصدارهما من لندن أول من

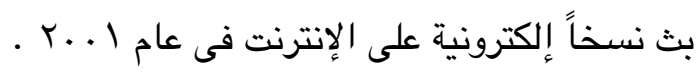
واليوم ، نجد على شبكة الإنترنت الآلاف من الصحف الإلكترونية سواء تابعة لمؤسسات صحفية أو نسخ إلكترونية لصحف مطبوعة أو صحف إلكترونيـة مستقلة أو غير ذلك ، حيث تثير الدراسات إلى أن الإقبال على تصفح الصحف الإلكترونية

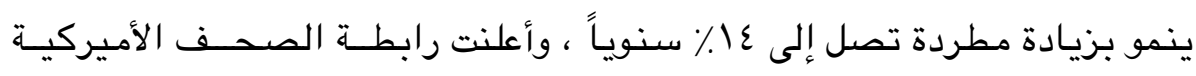
Newspaper Association of America

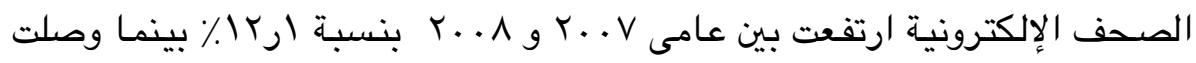


نسبة النمو إلى . اتح فى الأعوام الثلاثة الأخيرة .

هذه التحول الواضـح فى توجه القراء مـ الصحف التقليدية الورقية إلى النسخخ

الإلكترونية دفع الكثير من الأقلام والآراء إلى التكهن بانقراض الصحافة الورقية وربما

اختفاءها نهائياً بعد أعوام قليلة ، وقد يكون من المنطقى سيادة الصحافة الإلكترونية

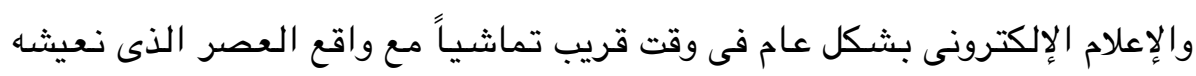

والمستقبل القريب الذى ستكون فيه الأجيال أكثر قدرة واستيعاباً لمفاتيح التكنولوجيا

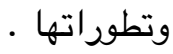

\section{| - ماهية|الصحف|الإكترونية}

تعددت تعاريف الصحف الإلكترونية ، وإن كان جميعها ينصب على استخدام شبكة

الإنترنت والاستخدام الرقمى لمحتوى تلك الصحف ، ومنها :

• هي تلك الصحف التى تستخدم شبكة الإنترنت للبث عليها وانتشـارها وتشمل المتن

والصور والرسـوم والصوت وجميع محتويات الجريدة المطبوعة كما تتيح مساحات

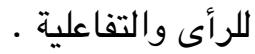

ويعرفها البعض بأنها التكامل بـين الكلمـة المكتوبة والتطور الرقمى مع استخدام

الفضـاء التخيلى فى توزيع ونـشر مـا تتضـمنه وتحتويه الصـحف من أخبار

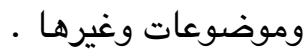

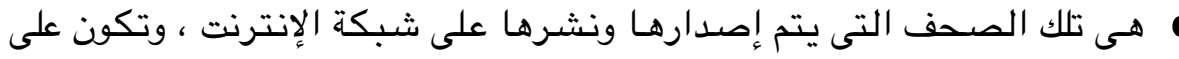

شكل جرائد مطبوعة على شاشـات الحاسبات الإلكترونية وتثمل صفحات الجريدة

المتن والصور والرسوم والصوت والصورة المتحركة(T) .

ويعرفها البعض بأنها : "وسيلة من وسائل الوسائط المتعددة Multimedia تتشر 
فيها الأخبار والمقالات وكافة الفنون الصحفية عبر شبكة المعلومات الدولية (الإنترنت) بشكل دورى وبرقم مسلسل ، بـاستخدام تقنيات عرض النصوص والرسوم والصور المتحركة وبعض الميزات التفاعلية ، وتصل إلى القارئ من خلال شـاشـة الحاسب الآلى سواء كان لها أصل مطبوع ، أو كانت صحيفة إلكترونية خالصة)(YV)

كما تعرف بـأنها : "جزء من مفهوم واسـع وأشـمل وهـو النشـر الإلكترونى الذى أنى لايعنى فقط مجرد استخدام أنظمة النشر المكتبى الإلكترونى وأدواته أو أنظمته المتكاملة ، بل يمتد حقل النشر إلى الإنترنت أو توزيع المعلومات والأخبار من خلال وصلات اتصسال عن بعد أو من خلال تقنية الوسـائط المتعددة وغيرهـا من النظم الاتصالية التى تعتمد على شبكة الحاسبات ، وتعتمد نظم النشر الإلكترونى عموماً التقنية الرقمية التى توفر القدرة على نقل ومعالجة النصوص والصوت والصورة

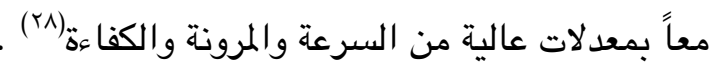
وتتميز الصحف الإلكترونية عن الصحف المطبوعة أو التقليدية بالكثير من الميزات ، لعل أهمها التفاعل بين الصحيفة والمستخدمين الموجودين فى الفضـاء التخيلى ، وكذا القـدرة على متابعة الأخبـار العالميـة وتحديث محتويـات الصحيفـة أولاً بأول ، كما تتميز أيضًا بـالانتشـار العالمى لها ، فهى صحف لا تتقيد بالزمـان أو المكان الجغرافى ، كمـا تتمتع هذه الصحف بعدم الخضوع للقيود المفروضة من الرقابة التى يمكن أن تُفرض على الصحف المطبوعة قبل النشر ، وبذلك نرى مـا تتمتع به هـذه الصـحف من حريـة فى نشـر الأخبار والموضسوعات بشكل لا تستطيع الصحف الورقية الحصول عليه أو التمتع به . كما تتميز الصحف الإلكترونية بخاصيتى المرونة والتنوع ، المرونة التى تتيح لها تجديد وتحديث موضسوعاتها على مدار السـاعة لتواكب الأحداث ، والمرونة التى تتيح 
للمستخدم الوصسول إلى الصحيفة الإلكترونية بسهولة مهما كانت إمكاناته فى التعامل مع الإنترنت ، أما خاصية التنوع فتظهر فى محتوى تلك الصحف التى تتضمن العديد من الموضسوعات والأقسـام الهائلة التى تتناقل بين النص المكتوب والمسـموع والمرئي ويـلك تجمع تلك الصـحف الإلكترونـية الخصـائص التى تتمتع بـها جميع وسـائل الإعـلام ، كما تتميز تلك الصحف الرقمية بإمكانية الاطلاع عليها فى أى مكان بالعالم

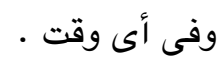

كما يرى بعض المهتمـين بالصـحافـة الإلكترونية أن هناك العديد من الفوائـــ التى استفاد منها مستخدمو شبكة الإنترنت والمتصفحون للصحف الإلكترونية ومنها (Y9) :

• إمكانية قراءة الصحف العالمية التى تصدر يومياً فضلاً عن المجلات والدوريات العلمية ، والأعمال الأدبية ، والأعمال الدرامية ... إلخ . الانفتاح على فروع المعرفة المختلفة سواء للمتخصصين أم غيرهم . الانفتاح على الثقافات المختلفة وسهولة التواصل بين المجتمعات الإنسـانية ، وإمكانية التفاعل بالصوت والصورة والكتابة والحوار ، ونقل المعلومات والوثائق والأفكار

إمكانية الوصول إلى الأشخاص والأماكن والمؤسسات بسهولة ويسر وتكلفة مادية أقل .

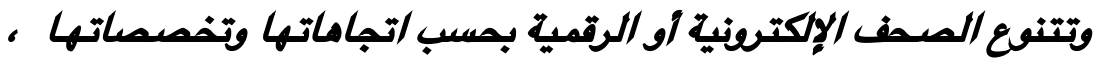

\section{: ومنه}

• الصحف التى تبث على مواقع تابعة لمؤسسـات صحفية تقليدية ، ويقوم على ظهور هذه الصحف ويثها على شبكة الإنترنت مبرمجون تابعون للمؤسسة تقتصر مهامهم على نقل ما تحتويه الصحيفة المطبوعة إلى الفضاء التخيلى بعد معالجته . 
الصحف الإلكترونية التلفزيونية (قنوات المعلومات) مثل المواقع الإخبارية كموقع الجزيـرة وموقع أريبيـا أون لاين وموقع أخبار جوجل .. وغير ذلك من المواقع

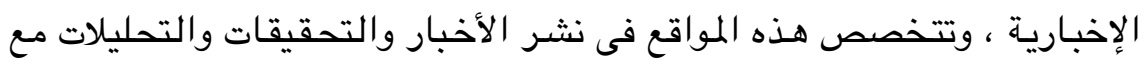
إتاحة الخدمة التفاعلية مع المستخدمين . الصحف الإلكترونية التى ليس لها مؤسسـات صحفية وتدار بجهد فردى وتعتمد

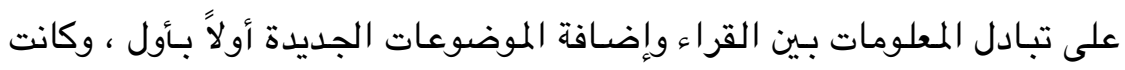
بداية ظهور هذه الصحف عام 1999 وتأسست لتعمل عبر الإنترنت والفضـاء

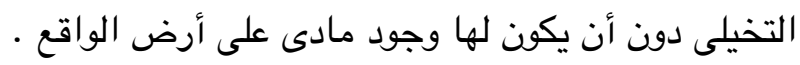
المواقع الإلكترونية الصحفية للجهات غير الإعلامية مثل الأحزاب والمنظمات والحكومات ، وتختص بنشر المعلومات المتعلقة بالجهة التابعة لها ، مع إتاحة خاصية التفاعلية مع المستخدمين ، وتقديم خدمات إلكترونية وإعلامية .

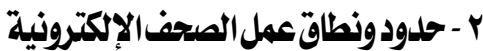

بالرغم من أن الدول تحافظ على حرية الرأى والتعبير بأى وسيلة ، ومنها الصحف الإلكترونية التى تتيح لمستخدمى الإنترنت التزود بالمعلومات والمثـاركة فيها ، إلا أن هذه الحرية ليست مطلقة ، بل مقيدة بما ورد بالمواثيق الدولية وإعلانات حقوق الإنسان

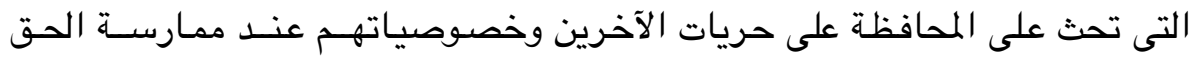
فى حرية التعبير عن الرأى ، كما تحث الدول مواطنيها على عدم تجاوز تلك الحرية للقوانين والثرائع السماوية والآداب العامة والنظام العام ، الأمر الذى جعل دولة مثل بريطانيا تصدر قوانين تعاقب انتهاك وسائل الإعلام لحق الخصوصية وحث هذه الوسائل باتخاذ الإجراءات لتنظيم نفسها وإصدار مواثيق أخلاقية تحمى الحياة الخاصة وتنظر فى شكاوى المواطنين ضد الصحف ، وكذا الكثير من الدول تنص فى 
تشريعاتها على حدود ونطاق العمل الصحفى وتوضح ما يعد خروجاً عن نطاق حرية الرأى والتعبير والعمل الصحفى كما بينا سلفاً .

بيد أن تصاعد ظهور الصحف الإلكترونية على شبكة الإنترنت بما تتمتع به من

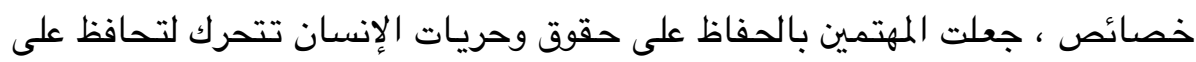

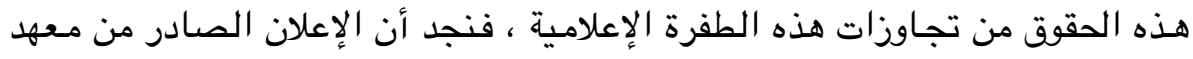
بوينتر 1997 ينص فى المادة الرابعة منه على تعهد محردى الصحف الإلكترونية على : (r.)

ه أن نكون حساسين تجاه حقوق الأفراد فى حماية حياتهم الخاصة عند إنتاج قواعد

$$
\text { البيانات . }
$$

أن نبث المعلومات عن حياة الأفراد الخاصة فى حالة أن تكون هناك مصلحة عامة

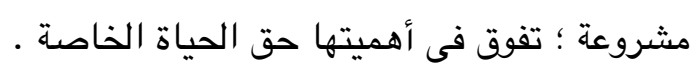

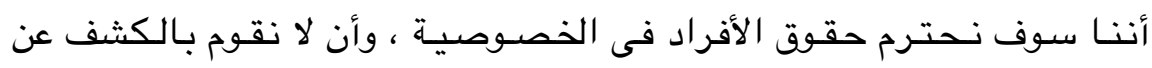

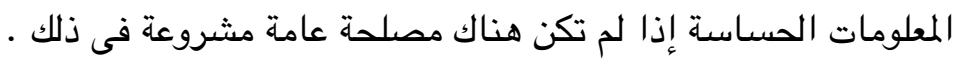

كما ظهرت المخاوف من التلاعب بالصور ، لذا قدمت الرابطة الأمريكية للصور

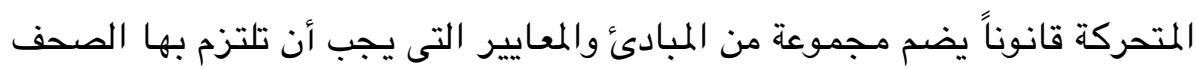
الإلكترونية ، وتضمن ضرورة احترام كرامة الإنسان وكبح ممارسة تصوير الأنشطة

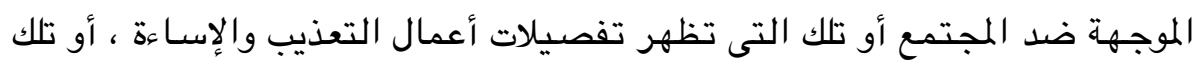

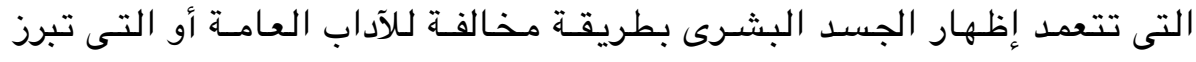

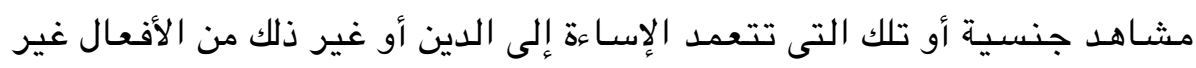

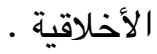

وإذا نظرنا إلى التشريعات التى تحكم عمل الصحف الإلكترونية نجد أن هناك

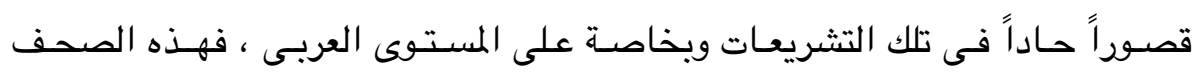

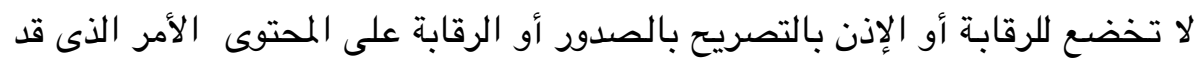


يؤدى إلى الخروج عن نطاق حرية التعبير عن الرأى ، بيد أن الكثير من الدول تطبق النصوص العامة لقانون العقوبات أو القوانين المتعلقـة بالصحافـة والنثــر والمطبوعـات أو أخرى ملحقة ، ويتم تطبيق تلك المواد القانونية على ما يبث على الصحف الإلكترونية أو ما تحتويه لتحدد نطاق المسئولية وتستطيع أن تحمى أمنها ومصالحها الوطنية وأمن مصالح مواطنيها هذا التطور فى ممارسـة حرية الرأى والتعبير عبر الصحف الإلكترونية كان له الأثر الفعال فى الحراك المجتمعى بجميع مظاهره ، حتى استطاع أن يسقط الحكومات ويكثف الفساد ، وهو الأمر الذى أدى إلى محاولة تقييده أو التعدى على تلك الصحف الإلكترونيـة ، سواء من جانب الحكومـات التى تجد نفسها وقد كثفت عوراتها فتلجأ للحجب أو إلقاء التهم ، أو من خلال بعض الأشخاص المعارضين لما يبث على صفحات تلك الصحف الإلكترونية ، فيتم ترجمة هذه المعارضـة بـاختراق المواقع الصحفية وتدميرهـا أو تدوين آراء مخالفة ورسائل تهديد كما حدث مع موقع جريدة اليوم السابع المصرية الذى تم اختراقها من قبل متثددين إسلاميين . كما تلجـأ بعض الدول إلى استخدام برامـج الفلترة وبروتوكولات الاتصالات للتحكم فى المواقع التى يتم السماح لها أو منعها ، كما يتم استخدام بوابات إلكترونية تعرف باسم (Proxy Server) وهى برامج تستخدم لتعترض المعلومـات بين المصدر

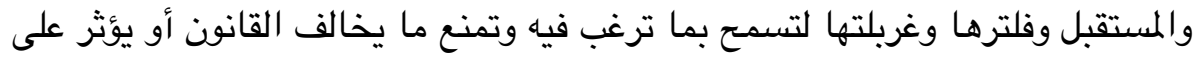
سلامة الوطن ، ولعل من الدول التى تستخدم تلك التقنيات على نطاق واسع الصين لمنع الكثير من صفقات البضـائع الأجنبية التى تسعى المواقع المعارضـة والمنشقة إلى لـ دخولها الأراضى الصينية ، كما فرضت سنفافورة على شـركات خدمات الإنترنت استعمال برامج الفلترة والمرشحات التكنولوجية لمنع مواقع معينة للبورنوجرافك (الصسور والأفلام الإبـاحية) ، بيد أن كثيراً من المواقع استطاعت أن تتجنب برامج

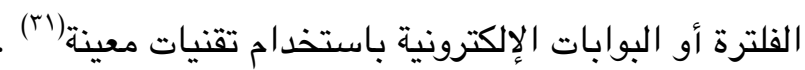




\section{الخاتهــة}

باستعراض الحق فى حرية الرأى والتعبير فى بيئة الإنترنت ، كأحد حقوق الإنسان

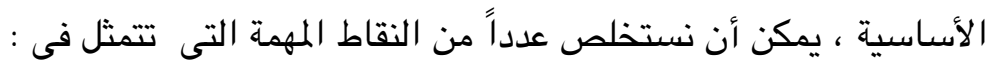

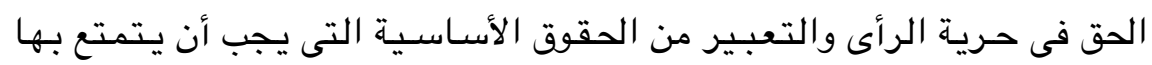

الإنسان ، وتؤكد عليها الشرائع السماوية والمواثيق والمعاهدات الدولية .

الحق فى حرية التعبير عن الرأى يذهب إلى قدرة الإنسان فى تكوين رأيه وعقيدته

دون تبعية أو ضغوط ، ويعبر عن هذا الرأى بحرية دون رقابة أو قيود .

الحق فى حرية التعبير عن الرأى حق مقيد بما ورد بالثرائع السماوية والمعاهدات

والمواثيق الدولية والتشريعات الوطنية من قيود تحمى حقوق الآخرين والنظام العام

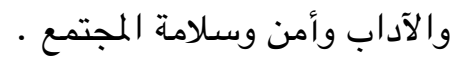

أن هناك فرقاً بين النقد البناء المباح وبين إبداء الرأى الذى يخرج عن نطاق وحدود

حرية الرأى والتعبير ، وبالتالى يقع تحت طائلة القانون ، مثل (السب - القذف -

التحريض - العيب أو الإهانة - مخالفة الآداب العامة - نشر أو إثـاعة أو ترويج

$$
\text { أخبار كاذبة - جرائم الصحف ل... إلخ) . }
$$

يتمتع مستخدمو شبكة الإنترنت بحرية التعبير عن الرأى طبقاً للمواثيق والمعاهدات الدولية والتشريعات الوطنية المعنية بذلك .

ت تتعدد أدوات ممارسة حرية التعبير عن الرأى فى بيئة الإنترنت ومنها الصحف الإلكترونية والنشر على المواقع والمنتديات والبريد الإلكترونى ومواقع الاتصال

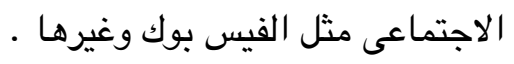


• يخضع التعبير عن الرأى فى بيئة الإنترنت أيضاً لما ورد بإعلان حقوق الإنسان والعهد الدولى للحقوق المدنية والسياسية وغيرهـا من المعاهدات والمواثيق الدولية

$$
\text { والتشريعات الوطنية . }
$$

• تتخذ بعض الدول فى كثير من الأحيان إجراءات قانونية ضد أصحاب المواقع أو

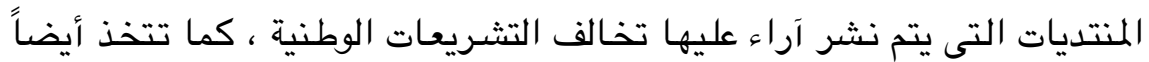

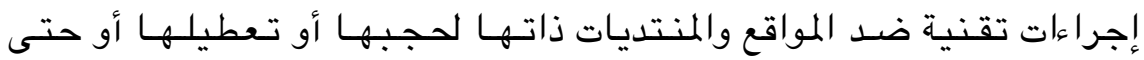

قرصنتها لمنع ما بها من آراء وحرمان مستخدميها من التعبير عن الرأى من

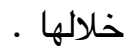

• تعد الصحف الإلكترونية والمنتديات من أهم أدوات ممارسة حرية التعبير عن الرأى

وأقواهـا فى البيئة الرقمية ، وتتميز بخصائص متعددة تميزها عن الصحف

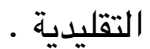


ا - غطاس ، جمال ، مقالات منشورة على شبكة الإنترنت للاطـلاع http//www.sste-eg.org

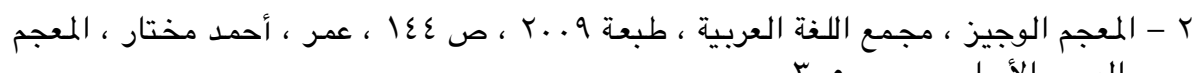

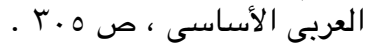

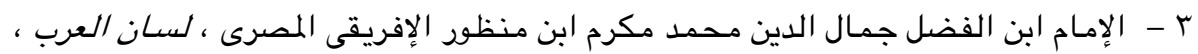

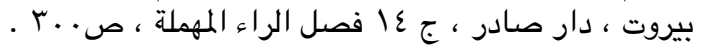

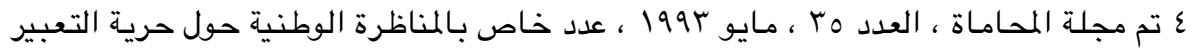

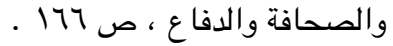

ه - بلدوى ، إسماعيل ، لدعائم الحكم فى الثـريعة الإسلامية والنظم الدستورية المعاصرة - دار

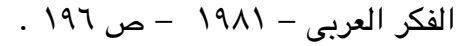

7 - النجار ، عماد عبد الحميد ، النقل المباح ، دار النهضة العربية ، 19VV ، ص اب . www.asbar.com : للمزيد راجع - V

^ تم عصر التنوير (أو ببساطة التنوير) هو عصر فى الفلسفة الغربية ، الفكرية والعلمية والثقافية ، وقل

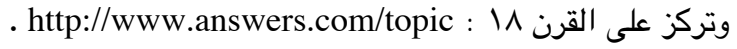

http://www.un/org/ar/documents/udhr/ 9

• ا- اتفاقية حماية حقوق الإنسان في نطاق مجلس أوروبا روما فى ع نوفمبر . 190 ، للاطلاع على

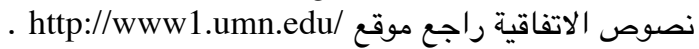

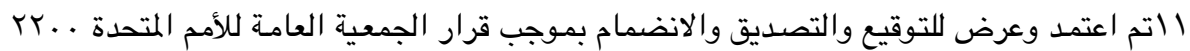

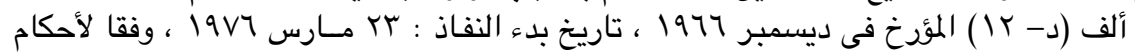

Www.oas.org/juridico.

r ا - للاطـلاع علـى الاتفاقيــة الأمريكية لحقوق الإنسان ميثاق سان خوسيه با - راجع نصوص الاتفاقيات الدولية السابق ذكرها سلفاً .

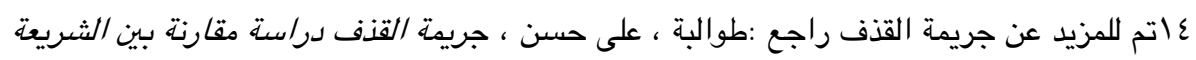

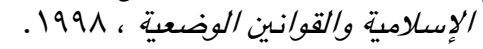

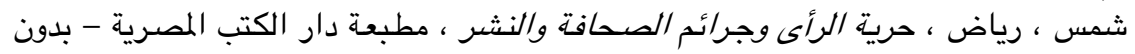

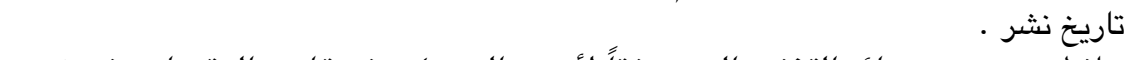

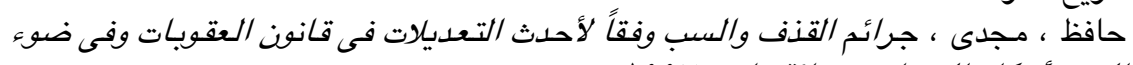

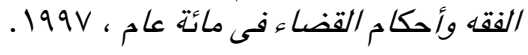

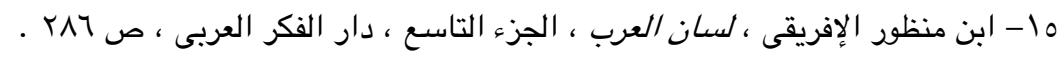

IV. 


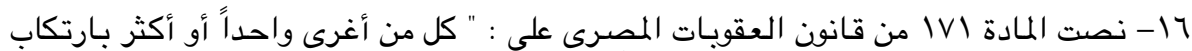

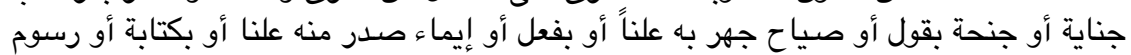

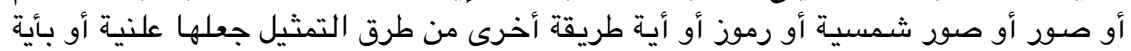

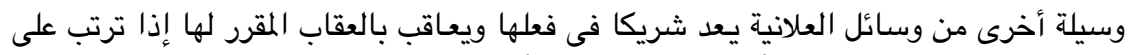

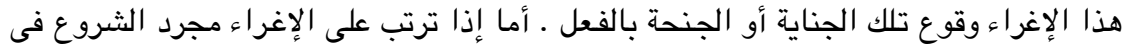

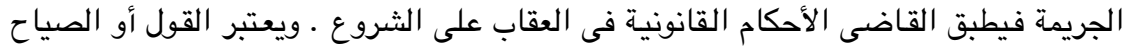

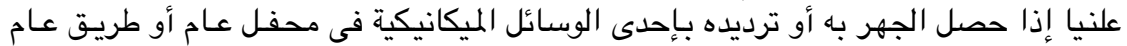

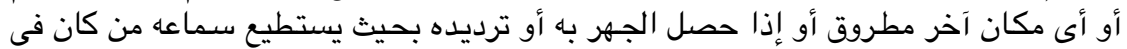

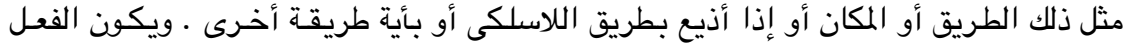

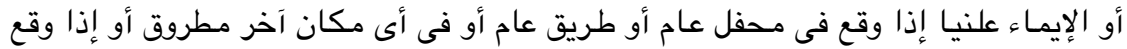

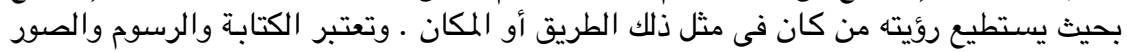

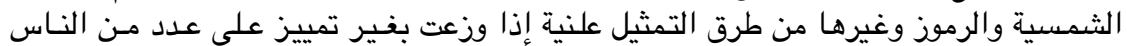

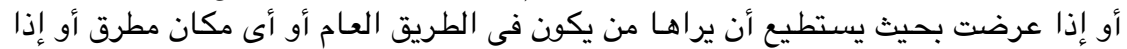

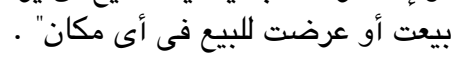
IV

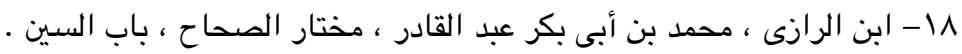

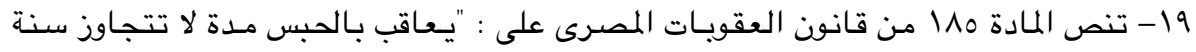

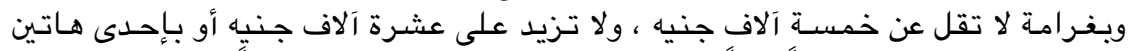

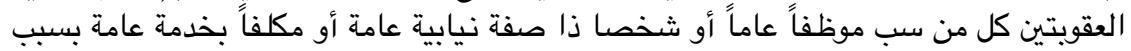

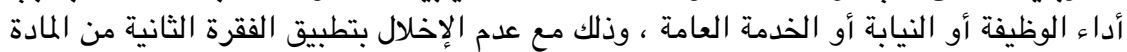

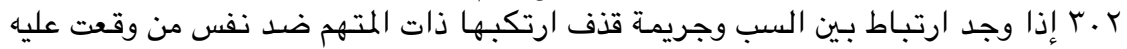

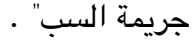
• ץ- ابن الرازى ، محمد بن أبى بكر عبد القادر ، مختار الصحاح ، باب الحاء.

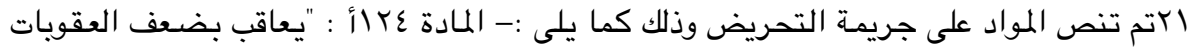

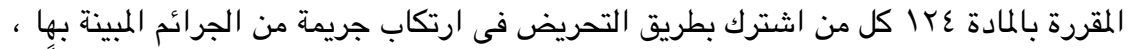

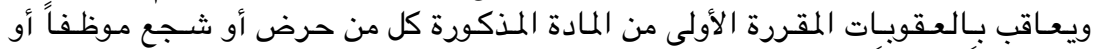

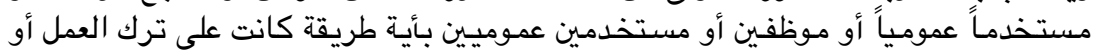

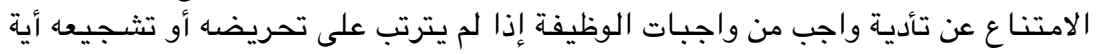

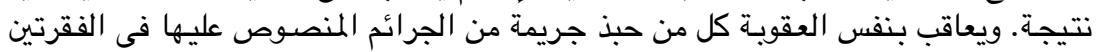

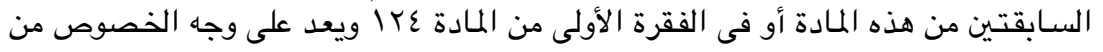

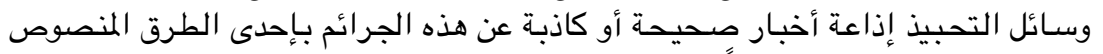

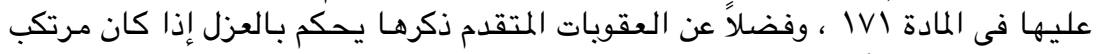

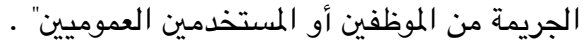

- المادة IVT : كل من حرض مباشرة على ارتكاب جنايات القتل أو النهب أو الحرق أو جنايات 


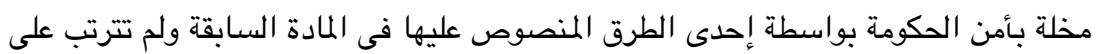

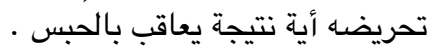

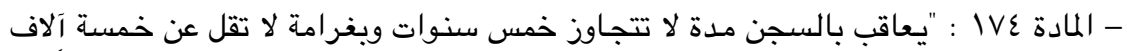

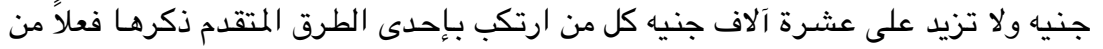

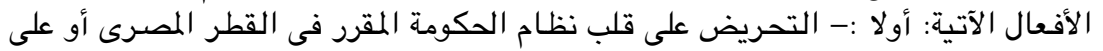

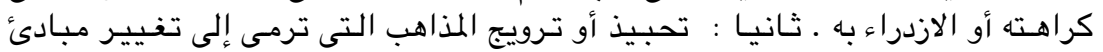

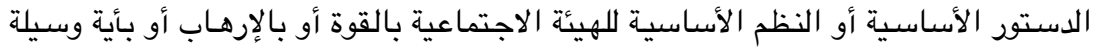

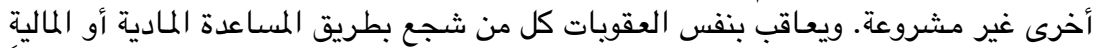

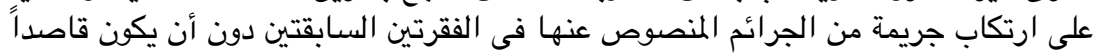

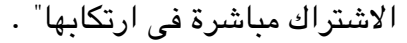

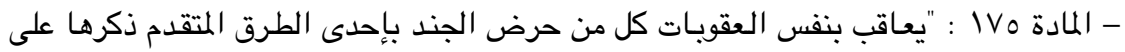

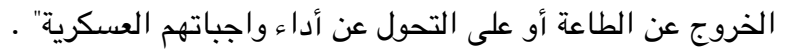

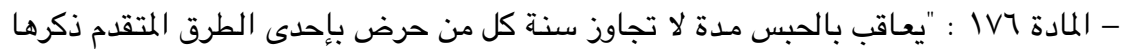

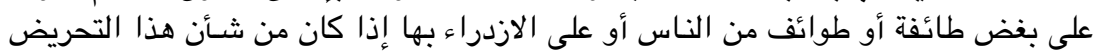

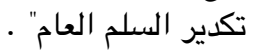

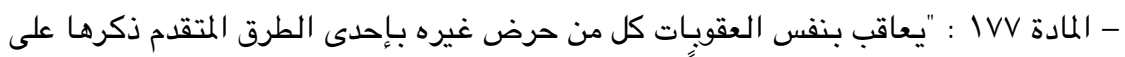

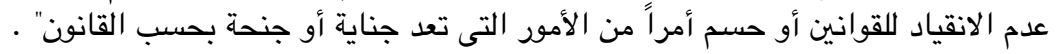

$$
\text { r }
$$

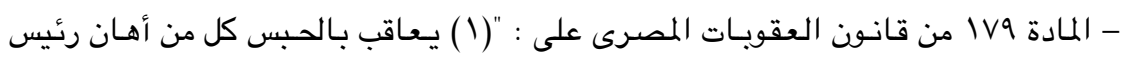

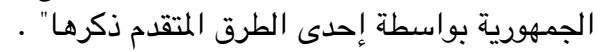

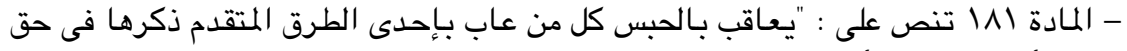

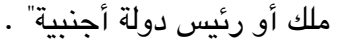

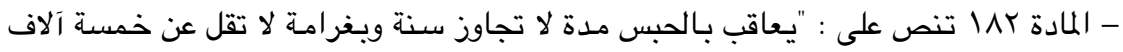

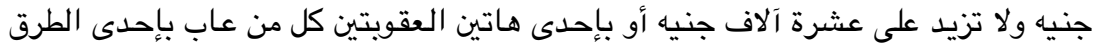

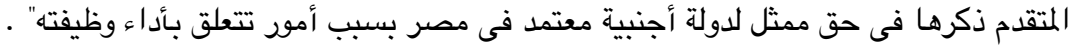

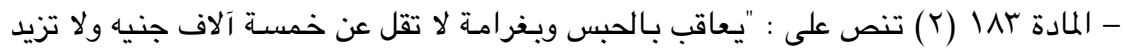

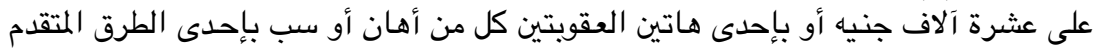

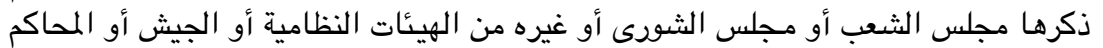

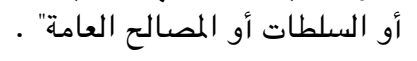

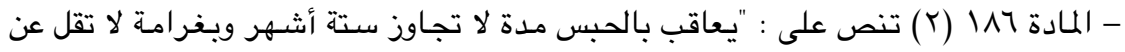

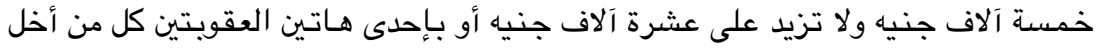

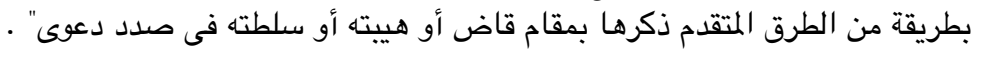




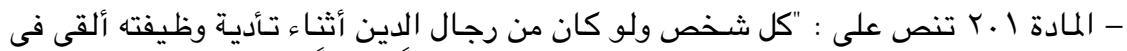

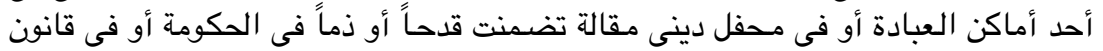

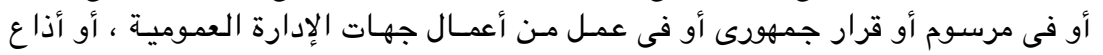

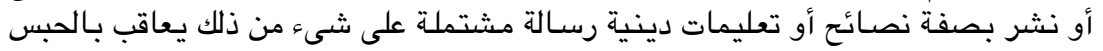

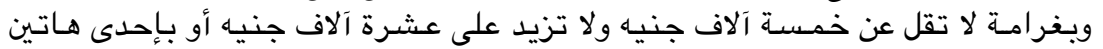

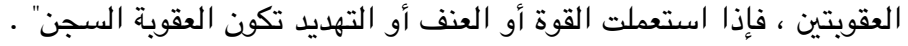

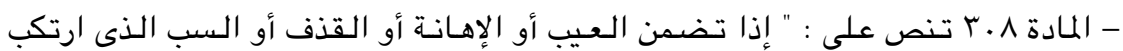

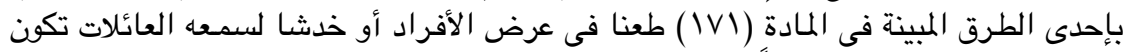

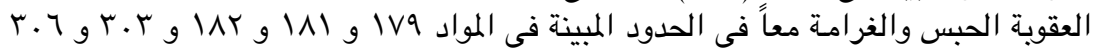

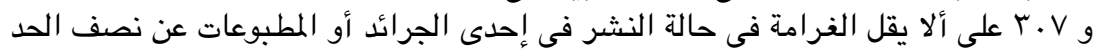

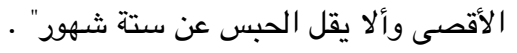

كזتم للمزيد راجع موقع : http://espacetunisien.com

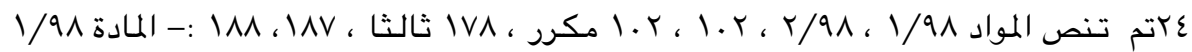

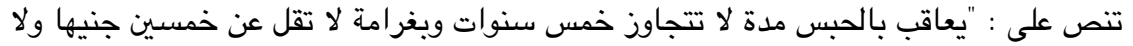

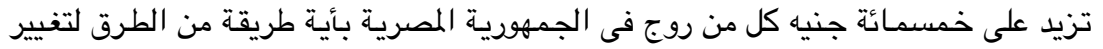

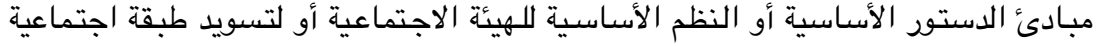

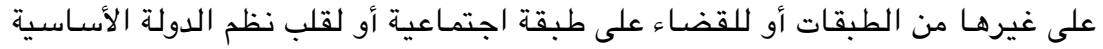

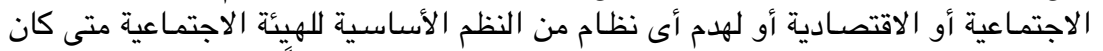

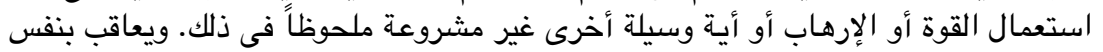

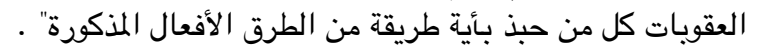

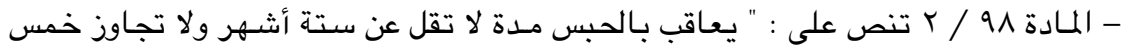

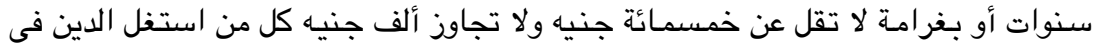

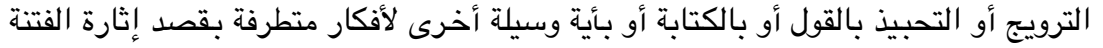

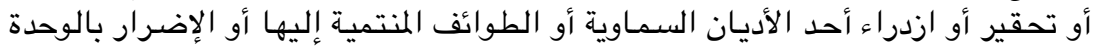

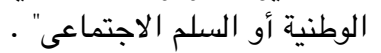

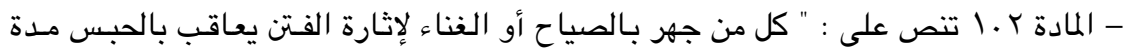

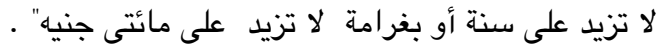

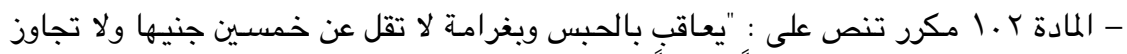

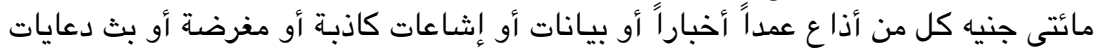

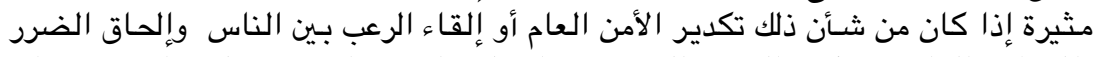

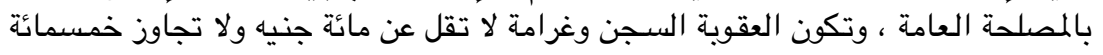

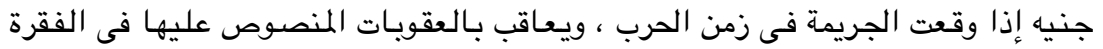

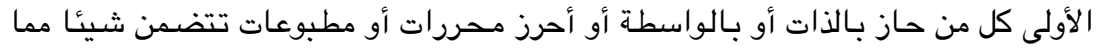

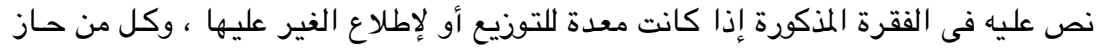

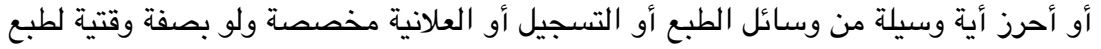
أو تسجيل أو إذاعة شيء مما ذكر" . 


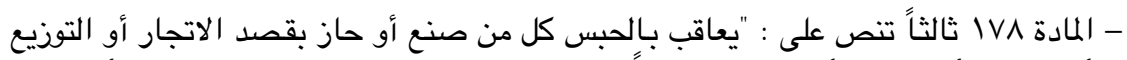

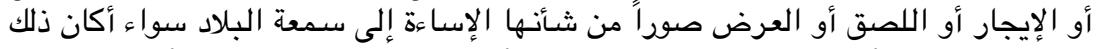
بمخالفة الحقيقة أو بإعطاء وصف غير صحيح أو بإبراز مظاهـر غير لائقة أو بأية طريقة الإنة

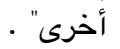

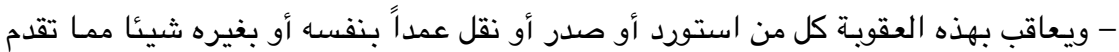

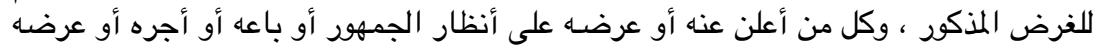

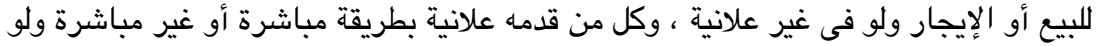
وسيلة . أل الإنيع - فإذا ارتكب الجرائم المنصوص عليها في هذه المادة عن طريق الصحف سرى فى شأنها حكم

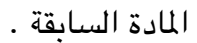

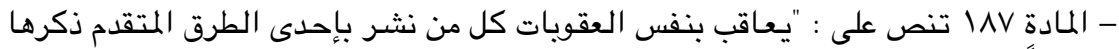

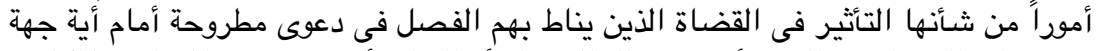

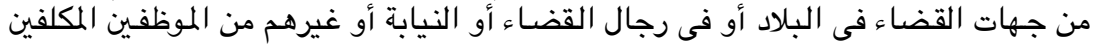

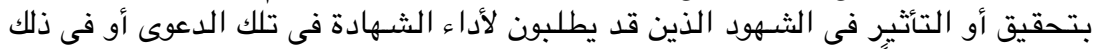

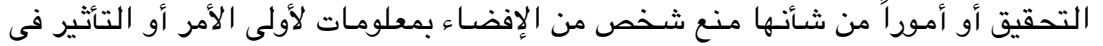

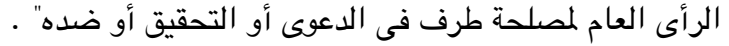

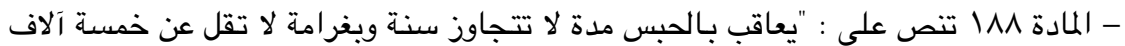

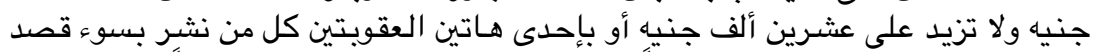

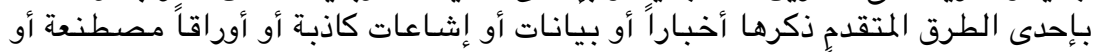

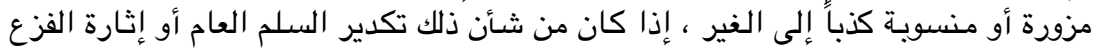

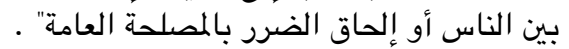

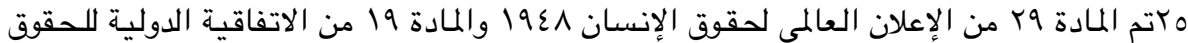

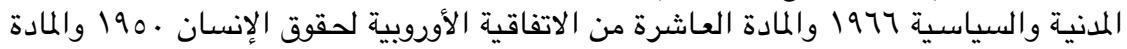

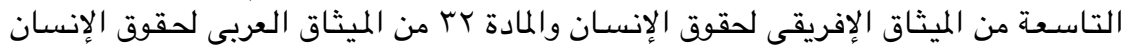

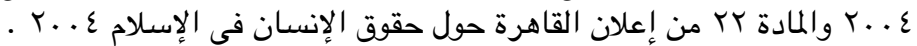

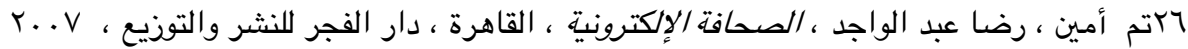
(

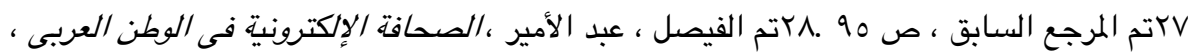

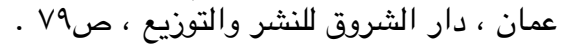

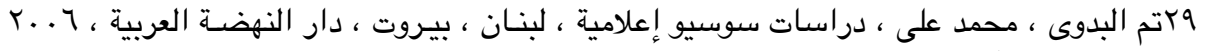

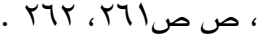

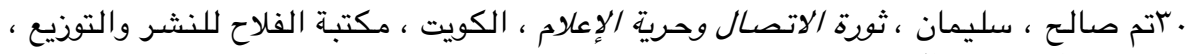
.r.V ص. r...V

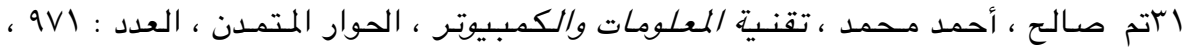
. http://www.ahewar.org/news/addn.asp ، r. . ع/q/ ^q 


\section{Abstract \\ FREE OPENION AND EXPRESSION \\ ON THE INTERNET}

Abu Serea' Ahmed

This study represents one of the most important rights for a person in Cyberspace, which is the freedom of expression on the internet .

It deals with the scope and limits of this right in international conventions and national legislation .

It also, clarifies the confusion between rights, responsibilities and duties among internet users to protect them from penalty of law . 